\title{
Temporal Variations of the Chemical Composition of Three Seaweeds in Two Tropical Coastal Environments
}

\author{
Andyara Nascimento', Carina Coelho-Gomes², Elisabete Barbarino, ${ }^{1,3}$, \\ Sergio Oliveira Lourenço ${ }^{1^{*}}$ \\ ${ }^{1}$ Department of Marine Biology, Fluminense Federal University, Niterói, Brazil \\ ${ }^{2}$ Maria Thereza College, Niterói, Brazil \\ ${ }^{3}$ Post-Graduate Programme in Chemistry, Fluminense Federal University, Niterói, Brazil \\ Email: $\underline{\text { solourenco@id.uff.br }}$
}

Received 4 December 2013; revised 19 January 2014; accepted 16 February 2014

Copyright (C) 2014 by authors and Scientific Research Publishing Inc.

This work is licensed under the Creative Commons Attribution International License (CC BY). http://creativecommons.org/licenses/by/4.0/

(c) (i) Open Access

\section{Abstract}

The seaweeds Chaetomorpha antennina, Gymnogongrus griffithsiae and Ulva fasciata were studied regarding tissue concentrations of total nitrogen, total phosphorus, total protein, hydrosoluble protein, total carbohydrate, chlorophyll $a$ and total carotenoid throughout a 39-month survey in two coastal environments of Rio de Janeiro State, Brazil. One of the sites (Itapuca Stone) has high concentrations of dissolved nutrients and an intense long-term process of cultural eutrophication; the second site (Bananal Inlet) is thought to have lower concentrations of dissolved nutrients and no relevant anthropic impact. Seaweeds experienced changes in the concentrations of the substances in the thalli; however they did not show any cyclic seasonal pattern, except for pigments, with lower values in summer in both sites. The differences found for each species in each sampling at the sites were small (e.g. U. fasciata, more total nitrogen at Itapuca Stone) or absent (e.g. C. antennina, no significant differences for hydrosoluble protein in the sites). Differences in the concentrations of dissolved nutrients in the sites did not generate contrasting chemical profiles in the seaweeds. There is no evidence of nitrogen- or phosphorus-limitation in any season. It is presumable that the concentrations of dissolved nutrients at the nutrient-poorer site are sufficient to generate high concentrations of the substances in the thalli of the species tested, similar to the concentrations measured in the eutrophic site. Experimental data are needed to elucidate the factors that promote the success of the species tested under contrasting nutrient availability and environmental disturbance.

\footnotetext{
*Corresponding author.
}

How to cite this paper: Nascimento, A., Coelho-Gomes, C., Barbarino, E. and Lourenço, S.O. (2014) Temporal Variations of the Chemical Composition of Three Seaweeds in Two Tropical Coastal Environments. Open Journal of Marine Science, 4, 118-139. http://dx.doi.org/10.4236/ojms.2014.42013 


\section{Keywords}

\section{Chemical Composition; Coastal Environments; Dissolved Nutrients; Seaweeds; Temporal Variations}

\section{Introduction}

Growth of macrophytes and phytoplankton in tropical coastal waters is generally limited by nutrient availability [1]. Human use of coastal areas has greatly increased the inputs of nitrogen and phosphorus into many aquatic systems, with resultant impacts at the population and ecosystem level [2]. Increased abundance of nuisance macroalgae is among the direct consequences of nutrient loading [3].

Studies on the abundance of opportunistic seaweeds and measurements of dissolved nutrients are traditional approaches used to add information to evaluate the trophic state of a given ecosystem. However, other parameters may also be used to assess some ecological characteristics of coastal environments. For instance, monitoring the concentration of total $\mathrm{N}$ and $\mathrm{P}$ in macroalgal tissues may be a more useful indicator of enrichment or eutrophication potential [4], since total nutrient concentration in the algal tissue integrates the nutrient regime over time [5] [6].

In addition to measurements of tissue $\mathrm{N}$ and $\mathrm{P}$, other chemical parameters can be useful in this field. Analyses of protein, carbohydrate and photosynthetic pigments can aggregate more information for the understanding of the behavior of algal species as responses to environmental conditions. Protein in the thalli is mainly influenced by nitrogen availability [7]. Both experimental and field studies have demonstrated that seaweeds tend to accumulate higher concentrations of protein and chlorophyll when dissolved nitrogen is available in high concentrations [8]. The values in the thalli tend to be relatively higher in specimens living in eutrophic environments or those that have been previously submitted to high concentrations of dissolved nutrients in a period before sampling [9].

High concentrations of carbohydrate in contrast with low concentrations of protein are frequently related to nitrogen deficiency in algae [10]. Under long-term short supply of nitrogen, it is observed that an increase in total carbohydrate and a progressive decrease of the concentration of nitrogenous substances (protein, pigments, intracellular inorganic nitrogen, nucleic acids, etc.) over time occur, and this is a universal behavior of seaweeds [7] [11] and microalgae [12]. Nitrogen-bearing substances may be partially consumed as alternative sources of nitrogen by algal species under nitrogen starvation [7] [12].

Data on pigment composition are also important to assess responses to environmental factors, such as temperature, salinity, dissolved nutrients and irradiation. The pigment content may increase in response to the environmental factors such as high nutrient availability [13] or decrease as a consequence of excess of solar radiation and exposure to UV radiation [14]. Damage caused by UV radiation may be especially relevant in tropical environments, where seaweeds are particularly exposed to high irradiation [14] [15].

Studies on tissue chemical composition of macroalgae are predominantly carried out in temperate environments [6] [13] [16]-[21]. By comparison, information on tissue chemical composition of algae from tropical and subtropical environments is relatively scarce [22]-[27], and more data are needed from the tropics.

In this study we report on the temporal variations of tissue $\mathrm{N}, \mathrm{P}, \mathrm{N}: \mathrm{P}$ atomic ratio, protein, carbohydrate, and photosynthetic pigments (chlorophyll and carotenoids) of the green algae Chaetomorpha antennina and Ulva fasciata and the red alga Gymnogongrus griffithsiae. The three macroalgal species are common in two tropical sites of Rio de Janeiro State, Brazil, with different trophic states: Bananal Inlet (oligotrophic-mesotrophic) and Itapuca Stone (eutrophic-hypereutrophic). Comparisons were made between algal substances and the concentrations of dissolved nutrients in the systems in this 3-year assessment to evaluate the effects of excess of nutrients on the chemical composition of the species studied.

\section{Materials and Methods}

\subsection{Sampling Sites}

Both sampling sites are located in Niterói municipality, State of Rio de Janeiro, Brazil (Figure 1). Bananal Inlet 


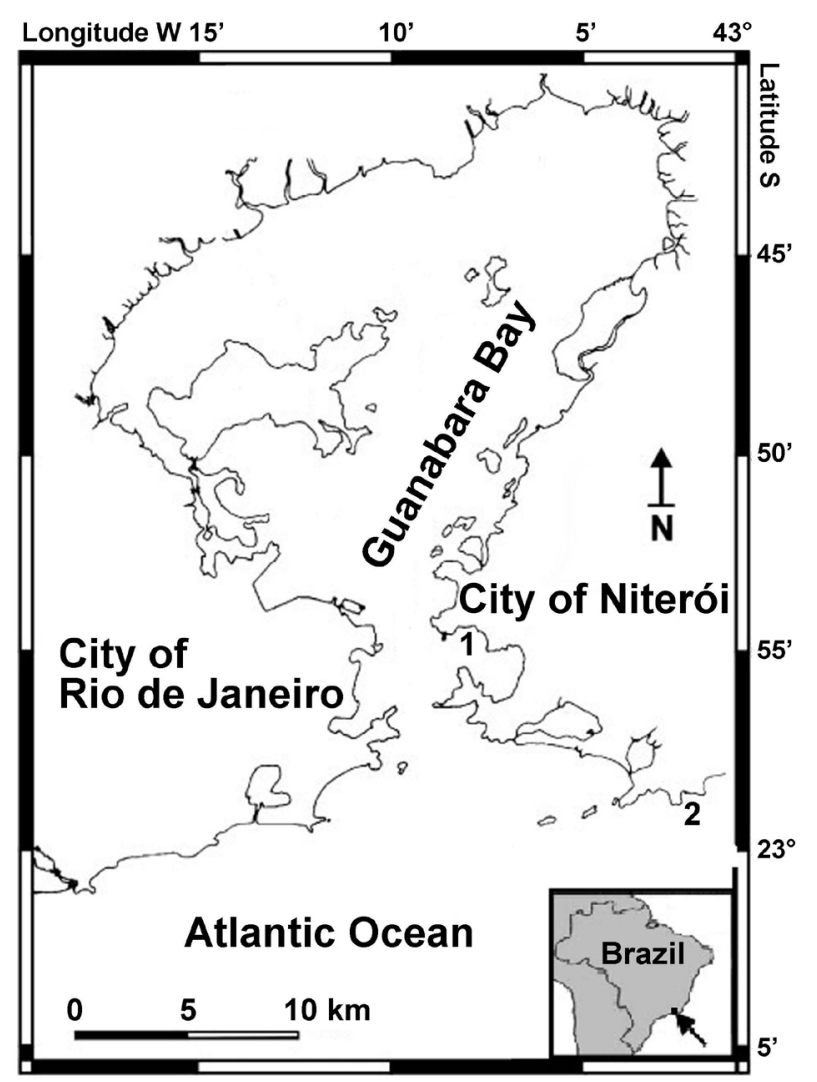

Figure 1. Sampling sites in Rio de Janeiro State, Brazil. $1=$ Itapuca Stone. 2 = Bananal Inlet.

$\left(23^{\circ} 58^{\prime} \mathrm{S}, 43^{\circ} 01^{\prime} \mathrm{W}\right)$ corresponds to the marine part of an environmental protected area (Serra da Tiririca State Park), with restricted access for recreational uses. The area is not inhabited, but human occupation can be seen close to the limits of the park (5 - $6 \mathrm{~km}$ away from the sampling site). The terrestrial part of the park is a mountain area covered by a tropical rain forest (Atlantic Forest). This site is considered protected from relevant human impacts. Macroalgal floristic studies are still scarce in this site, but preliminary results indicate the existence of 92 species at the intertidal zone (Moreira, unpublished data).

The second site is Itapuca Stone $\left(23^{\circ} 04^{\prime} \mathrm{S}, 43^{\circ} 08^{\prime} \mathrm{W}\right)$, located in Guanabara Bay. The site is in the urban area of Niterói City, and it is located near the entrance of the Bay (Figure 1), which promotes a local dilution in the typical high levels of pollution of this coastal system and a faster water turnover [28]. Inner areas of Guanabara Bay show a low water exchange rate [29] due to geomorphological features and human occupation of coastal areas. The Bay comprises an area of $381 \mathrm{~km}^{2}$ and an estimated 2-billion $\mathrm{m}^{3}$ of water. Its hydrographic basin $\left(4000 \mathrm{~km}^{2}\right)$ includes 35 rivers that contribute substantially to the freshwater input. Guanabara Bay is considered a eutrophic or hypereutrophic environment (depending on the specific part of the Bay), highly disturbed by anthropic impacts [30].

Considering the environmental characteristics described here, we hypothesized that the seaweeds of Itapuca Stone (Guanabara Bay) would present permanently high concentrations of tissue N and P; in addition, the seaweeds in Itapuca Stone would not show significant variations in their tissue substances throughout the year and no inter-annual changes in the chemical substances analyzed. On the other hand, temporal changes in algal tissue substances would be expected for the seaweeds of Bananal Inlet.

\subsection{Seaweeds}

Three macroalgal species were analyzed, and their identification was carried out following a widely accepted checklist [31]. Chlorophyta: Chaetomorpha antennina (Bory) Kützing and Ulva fasciata L. Rhodophyta: Gymnogongrus griffthsiae (Turner) Mart. 


\subsection{Sampling}

Sampling began in December 2000 (end of the austral spring) and continued through February 2004 (austral summer). Samples were collected every 30 - 75 days, depending on the tidal regime and season. Samples were collected in the intertidal area only.

Whole thalli of adult plants were collected in early morning and washed in the field with seawater to remove epiphytes, sediment and detritus. At least 15 whole plants of each species were collected, independent of the size of each seaweed. All species were typically found at the same specific points in the site throughout the study (e.g. C. antennina was sampled always at the same rocks). The plants were placed in plastic bags, and kept on ice until return to the laboratory (less than one hour). In the laboratory, samples were gently brushed under running seawater, rinsed with distilled water, and dried at $60^{\circ} \mathrm{C}$ for at least three days and until constant weight, to determine the percentage of moisture in the tissues. The dried material was ground into a powder and kept in desiccators containing silica-gel at room temperature until $\mathrm{N}$ and $\mathrm{P}$ tissue analyses.

Samples for pigment were analyzed immediately after the preparation of the algal material, in the same day of the field trip, using wet thalli. Samples for protein and carbohydrate were cleaned, weighted (wet weight) and stored at $4^{\circ} \mathrm{C}$ until analyses, up to five days later. At the time of each collection of macroalgae, four $250 \mathrm{ml}-w a-$ ter samples $(n=4)$ for dissolved nutrient analysis were taken from 15 - $20 \mathrm{~cm}$ below the water surface, as well as measurements of local temperature at the same depth. The samples of water were filtered through cellulose membrane filters (Millipore ${ }^{\circledR}$ HAWP $0.45 \mu \mathrm{m}$ pore) and kept at $-20^{\circ} \mathrm{C}$ until spectrophotometric determinations of dissolved nutrients. Each sample was measured at least three times to obtain accurate results, and the results showed in this study represent mean values for four independent samples collected in the field for each sampling.

\subsection{Tissue Analyses}

Total $\mathrm{N}$ and $\mathrm{P}$ were determined in algal tissue after peroxymonosulphuric acid digestion, using a Hach digestor (Digesdhal ${ }^{\circledR}$, Hach Co.) [32]. Total N and P contents in the samples were determined spectrophotometrically after specific chemical reactions. For analytical details see Lourenço et al. [15]. For each species and sampling four independent (from different plants) measurements of tissue $\mathrm{N}$ and $\mathrm{P}$ were performed $(\mathrm{n}=4)$.

The Lowry et al. method [33] was used to evaluate hydrosoluble protein in the samples, with bovine serum albumin as a protein standard. Spectrophotometric determinations were done at $750 \mathrm{~nm}$. Results obtained for total nitrogen were used to calculate the total protein content, using the nitrogen-to-protein conversion factors proposed by Lourenço et al. [34]. Carbohydrate was extracted with $80 \% \mathrm{H}_{2} \mathrm{SO}_{4}$, according to Myklestad \& Haug [35] and determined spectrophotometrically at $485 \mathrm{~nm}$ by the phenol-sulphuric acid method [36], using glucose as a standard. Pigment extraction was performed in methanol, at $4^{\circ} \mathrm{C}$, for $20 \mathrm{~h}$. Chlorophyll $a$ and total carotenoid was determinated spectrophotometrically as described by Lorenzen [37] and Strickland \& Parsons [38], respectively.

\subsection{Dissolved Nutrients}

For the quantification of nutrient ions in seawater, spectrophotometric determinations of nitrate and nitrite [39], ammonium/ammonia [40], urea and phosphate [41] were performed, following standard procedures.

\subsection{Physical and Meteorological Parameters}

Salinity was measured with a hand refractometer (Shibuya Optical, model S-10) using four samples $(\mathrm{n}=4)$ collected in the field in each trip. Air temperature and seawater temperatures were measured with a mercury-column thermometer (Incoterm Co., Brazil).

Meteorological data (average monthly air temperature and precipitation) were obtained from the Fluminense Federal University Meteorological Station, located in Niterói, beside Guanabara Bay.

\subsection{Statistical Analysis}

The results for each species separately and for total measurements of all species combined were analysed by single-factor analysis of variance (ANOVA) with significance level $\alpha=0.05$ [42], followed with a Tukey's multiple 
comparison test. Suitable transformations of data (e.g. log of the actual data) were made when necessary. Time was the only factor considered in ANOVA.

\section{Results}

Table 1 shows small temperature variations throughout the study. Maximum temperatures tended to be achieved in December-February (austral summer). Maximum monthly average temperatures were obtained in December 2003 and February 2004. Similar trends were obtained for atmospheric precipitation, with higher values obtained in summer months, and a maximum record in December 2001.

Measurements of salinity were typically lower at Itapuca Stone, where they fluctuated between 29.5 and 34.9 psu throughout the study (Table 2). At Bananal Inlet, minor variations in salinity were recorded, with values fluctuating around 35 psu (except in January 2004, when 31.2 was recorded). Conversely, variations in water temperature were wider in Bananal Inlet, with a difference between maximum and minimum mean values of $9^{\circ} \mathrm{C}$ (Table 2), ca. three times that recorded at Itapuca Stone $\left(3^{\circ} \mathrm{C}\right)$. Air temperatures during field trips were similar in both sampling sites, however higher variations were recorded at Bananal Inlet.

In general, higher concentrations of all dissolved nutrients were found at Itapuca Stone, although in some observations the concentrations of nutrients were similar in both sites (Table 3). Typical concentrations of ammonium/ammonia were $>5 \mu \mathrm{M}$ at Itapuca Stone and $<2 \mu \mathrm{M}$ at Bananal Inlet, with significant differences between the sites ( $\mathrm{p}<0.0001)$. In Itapuca Stone, nitrite concentrations were typically ca. three times higher than those of Bananal Inlet $(\mathrm{p}<0.0001)$, and a similar trend was recorded for nitrate. At Bananal Inlet maximum values for nitrate and nitrite were found in late summer/early autumn (Table 3). Urea tended to show higher concentrations in late spring and in summer, and lower values in winter, with higher concentrations at Itapuca Stone $(\mathrm{p}=$ 0.0231). Total nitrogen was influenced mainly by dissolved ammonium/ammonia and nitrate, the nitrogenous ions presented in higher concentrations in both sampling sites. Higher values for total nitrogen tended to be achieved in summer at Bananal Inlet (maximum of $12.4 \mu \mathrm{M}$, January 2004), and in winter at Itapuca Stone (maximum of $36.2 \mu \mathrm{M}$, July 2003). Typical concentrations of phosphate were ca. three times higher at Itapuca Stone than at Bananal Inlet $(\mathrm{p}<0.0001)$, however the $\mathrm{N}$ :P atomic ratio were similar for both sites $(\mathrm{p}=0.38)$, with overall fluctuations around 15:1 in seawater.

Wide variations among the three species were found for total tissue nitrogen (Figure 2). G. griffithsiae and $U$. fasciata tended to show higher concentrations of tissue nitrogen, while C. antennina presented lower values. In many comparisons $U$. fasciata showed differences for the measurements obtained in the sites, with higher values at Itapuca Stone. For the other species differences were small or not significant for monthly comparisons of the sites. C. antennina showed minor variations in tissue phosphorus throughout the study in both sites (Figure 3). A similar trend was obtained for G. griffithsiae, but in some comparisons higher values were recorded at Bananal Inlet. Among the three seaweeds, $U$. fasciata showed wider variations in tissue phosphorus in this study, with a trend to show higher concentrations of tissue $\mathrm{P}$ at Itapuca Stone.

Variations in tissue N:P ratio were wider for G. griffithsiae, varying from 10:1 (Bananal Inlet, December 2000) to 34:1 (Itapuca Stone, January 2003). For most of the comparisons, values of tissue N:P ratio were not significantly different in both sites for the three species (Figure 4).

As total protein was calculated using nitrogen-to-protein conversion factors, the same general trends described for total nitrogen were found (Figure 5). Typical values for hydrosoluble protein were higher than 15\% of d.w., with $U$. fasciata showing percentages higher than the other species in most observations (Figure 6). Changes in hydrosoluble protein followed the same general description presented for tissue $\mathrm{N}$ and total protein, with $U$. fasciata showing more protein at Itapuca Stone, and small or null differences between the sites for the other species.

Carbohydrate was the most abundant component for all species, with typical concentrations $>40 \%$ d.w. in almost all measurements (Figure 7). G. griffithsiae showed maximum concentrations of total carbohydrate, with more than $60 \%$ of d.w. in some observations. G. griffithsiae tended to show higher concentrations of total carbohydrate in Bananal Inlet throughout the study.

Clorophyll $a$ and total carotenoid showed wide variations in the measurements throughout the study (Figure 8 and Figure 9). C. antennina showed virtually the same concentrations of clorophyll $a$ and total carotenoid in both sites, but G. griffithsiae tended to present higher concentrations in Bananal Inlet and $U$. fasciata at Itapuca Stone. For all species lower values were measured after the summer, and higher values tended to be found in autumn and winter. 
Table 1. Atmospheric precipitation and air temperature collected daily at the Fluminense Federal University Meteorological Station throughout the period of this study.

\begin{tabular}{|c|c|c|c|c|c|}
\hline \multirow[t]{2}{*}{ Month/year } & \multicolumn{2}{|c|}{ Precipitation (mm) } & \multicolumn{3}{|c|}{ Air temperature $\left({ }^{\circ} \mathrm{C}\right)$} \\
\hline & Average & Total & Minimum & Average & Maximum \\
\hline Nov/2000 & 1.8 & 57.2 & 21.8 & 24.9 & 29.2 \\
\hline Dec/2000 & 3.1 & 94.8 & 22.9 & 26.3 & 31.3 \\
\hline Jan/2001 & 2.2 & 66.8 & 23.2 & 27.0 & 32.7 \\
\hline Feb/2001 & 3.4 & 95.6 & 24.2 & 28.3 & 35.0 \\
\hline Mar/2001 & 2.1 & 65.4 & 23.4 & 27.6 & 34.3 \\
\hline Apr/2001 & 0.2 & 4.8 & 22.3 & 26.3 & 32.4 \\
\hline May/2001 & 2.5 & 78.2 & 19.9 & 23.5 & 29.0 \\
\hline Jun/2001 & 2.0 & 56.8 & 19.5 & 23.0 & 28.3 \\
\hline $\mathrm{Jul} / 2001$ & 2.3 & 72.4 & 20.2 & 23.5 & 27.2 \\
\hline Aug/2001 & 0.2 & 5.4 & 22.5 & 24.8 & 29.0 \\
\hline Sep/2001 & 2.0 & 30.8 & 22.9 & 25.9 & 30.4 \\
\hline Oct/2001 & 1.6 & 49.2 & 23.4 & 26.6 & 31.9 \\
\hline Nov/2001 & 3.4 & 101.0 & 23.2 & 25.9 & 30.8 \\
\hline Dec/2001 & 8.1 & 251.8 & 23.7 & 27.7 & 33.8 \\
\hline Jan/2002 & 2.1 & 65.2 & 22.5 & 26.3 & 32.1 \\
\hline Feb/2002 & 4.1 & 114.4 & 21.3 & 24.9 & 30.4 \\
\hline Mar/2002 & 1.0 & 31.6 & 20.1 & 23.5 & 29.1 \\
\hline Apr/2002 & 0.1 & 4.4 & 18.9 & 21.9 & 26.3 \\
\hline May/2002 & 5.1 & 157.2 & 20.0 & 23.7 & 29.3 \\
\hline Jun/2002 & 1.9 & 23.2 & 18.9 & 21.9 & 26.2 \\
\hline Jul/2002 & 0.8 & 24.8 & 21.2 & 25.2 & 31.0 \\
\hline Aug/2002 & 0.6 & 18.6 & 22.4 & 25.9 & 31.1 \\
\hline Sep/2002 & 2.9 & 87.2 & 23.5 & 26.7 & 31.6 \\
\hline Oct/2002 & 0.9 & 28.8 & 23.9 & 27.1 & 32.5 \\
\hline Nov/2002 & 7.0 & 108.6 & 23.9 & 28.2 & 34.8 \\
\hline Dec/2002 & 5.5 & 171.6 & 23.6 & 27.5 & 33.8 \\
\hline Jan/2003 & 6.8 & 211.8 & 22.1 & 25.9 & 31.5 \\
\hline Feb/2003 & 0.1 & 1.8 & 19.2 & 23.0 & 28.6 \\
\hline Mar/2003 & 6.7 & 208.8 & 18.7 & 23.0 & 29.7 \\
\hline Apr/2003 & 1.9 & 56.0 & 17.2 & 21.6 & 27.8 \\
\hline May/2003 & 1.6 & 49.0 & 17.4 & 21.2 & 26.5 \\
\hline Jun/2003 & 1.5 & 45.4 & 18.9 & 22.4 & 27.1 \\
\hline $\mathrm{Jul} / 2003$ & 0.9 & 29.0 & 20.0 & 23.6 & 28.7 \\
\hline Aug/2003 & 1.0 & 32.0 & 21.8 & 25.3 & 30.3 \\
\hline Sep/2003 & 3.0 & 90.0 & 23.0 & 26.3 & 31.3 \\
\hline Oct/2003 & 4.3 & 132.0 & 22.5 & 25.7 & 30.3 \\
\hline Nov/2003 & 6.4 & 192.4 & 22.6 & 26.1 & 31.2 \\
\hline Dec/2003 & 3.8 & 116.8 & 21.8 & 24.9 & 29.2 \\
\hline Jan/2004 & 4.9 & 152.4 & 22.9 & 26.3 & 31.3 \\
\hline Fev/2004 & 4.4 & 127.8 & 23.2 & 27.0 & 32.7 \\
\hline
\end{tabular}


Table 2. Average values of salinity and temperature measured at the sampling sites during part of the field trips. Results for salinity represent the mean values of four determinations \pm the standard deviation $(n=4)$. Data for the first 18 months of this study are not presented.

\begin{tabular}{ccccccc}
\hline Sampling & \multicolumn{2}{c}{ Salinity (psu) } & \multicolumn{2}{c}{ Seawater temperature $\left({ }^{\circ} \mathrm{C}\right)$} & \multicolumn{2}{c}{ Air temperature $\left({ }^{\circ} \mathrm{C}\right)$} \\
\hline & Itapuca Stone & Bananal Inlet & Itapuca Stone & Bananal Inlet & Itapuca Stone & Bananal Inlet \\
\hline Aug/2002 & 33.9 & 34.6 & 24.0 & 22.0 & 23.5 & 21.5 \\
Oct/2002 & 33.9 & 35.4 & 23.0 & 19.0 & 25.0 & 22.0 \\
Nov/2002 & 33.7 & 35.2 & 25.0 & 23.5 & 26.7 & 25.0 \\
Dec/2002 & 29.5 & 34.9 & 25.0 & 21.0 & 25.5 & 25.0 \\
Jan/2003 & 30.2 & 34.9 & 26.0 & 23.5 & 28.0 & 25.2 \\
Feb/2003 & 32.1 & 36.2 & 24.0 & 27.0 & 28.0 & 27.0 \\
Mar/2003 & 34.9 & 35.1 & 26.0 & 26.0 & 26.5 & 26.0 \\
May/2003 & 34.8 & 35.2 & 23.5 & 25.0 & 25.5 & 25.5 \\
Jun/2003 & 34.7 & 35.0 & 23.0 & 23.0 & 24.0 & 20.5 \\
Jul/2003 & 34.1 & 34.9 & 23.0 & 22.5 & 23.0 & 22.0 \\
Aug/2003 & 32.1 & 34.9 & 23.0 & 22.0 & 22.5 & 21.7 \\
Sep/2003 & 34.5 & 35.0 & 23.0 & 23.0 & 23.0 & 23.5 \\
Nov/2003 & 33.7 & 34.1 & 25.5 & 23.0 & 27.0 & 24.5 \\
Jan/2004 & 31.5 & 31.2 & 24.5 & 17.0 & 26.5 & 23.0 \\
Feb/2004 & 29.6 & 35.8 & 25.5 & 18.0 & 26.0 & 23.0 \\
\hline
\end{tabular}

\section{Discussion}

\subsection{Dissolved Nutrients}

Results confirmed that concentrations of dissolved nutrients at Itapuca Stone were higher than at Bananal Inlet, but the differences between the sites were not intense. In some observations no statistical difference was detected between the sites, and in some monthly comparisons the absolute values measured in Bananal Inlet were only $30 \%$ - 50\% lower than in Itapuca Stone.

Some hypotheses can be considered to explain the small differences in dissolved nutrients in the sites. The Inlet is the marine part of the Serra da Tiririca State Park, with most of its area comprising a rain forest on mountains. The topographical characteristics of the area possibly favor the transport of nutrients from the forest soil to the Inlet, especially after rainfalls. As a typical concentration of nitrogen in soil may be three orders of magnitude higher than that of the seawater, the run-off of relatively small fractions of nutrients from the forest would promote a remarkable fertilization of the seawater in the Inlet. If this interpretation is correct, inputs of organic substances (e.g. humic acids) probably are also relevant in Bananal Inlet. In this scenario, the forest that surrounds the sampling site could play as an important factor for the input of nutrients into the site. The influence of run-off from an adjacent forest to algal communities has already been shown [43]. These authors demonstrated that the run-off from a forest in the east coast of South Korea promoted a remarkable increase in heavy metals, especially cadmium, detected in the algal flora besides a relevant nutrient enrichment.

A second hypothesis refers to the effects of the water circulation in the region. Despite the Inlet is an inhabited area, it is close to urbanized districts of Maricá, Niterói and Rio de Janeiro municipalities. The short distance to urban areas would favor the input of seawater with high concentrations of nutrients (and even pollutants) in Bananal Inlet. The entrance of Guanabara Bay is ca. $20 \mathrm{~km}$ to the Inlet, and the Bay itself is an important source of dissolved nutrients to adjacent areas [44]. These arguments are hypothetic, but there is some evidence to corroborate with this interpretation. For instance, in some field trips it was possible to detect the presence of solid waste (plastic, paper, etc.), in moderate amounts, floating in the Inlet. The occurrence of these records had 
Table 3. Some selected mean values for dissolved nutrients collected throughout the present study in the two sampling sites. The results are expressed as $\mu \mathrm{M}$ (except N:P ratio) and represent the average of four replicates \pm SD $(n=4)$.

\begin{tabular}{|c|c|c|c|c|c|c|c|}
\hline & \multicolumn{7}{|c|}{ Nutrient } \\
\hline & N-Ammonia & N-Nitrite & N-Nitrate & N-Urea & Total N & Phosphate & $\mathrm{N}: \mathrm{P}$ ratio \\
\hline \multicolumn{8}{|l|}{ Dec/2000 } \\
\hline Itapuca Stone & $14.7 \pm 4.65$ & $0.70 \pm 0.14$ & $3.02 \pm 1.76$ & $1.85 \pm 0.38$ & $20.2 \pm 3.47$ & $2.68 \pm 0.83$ & $7.56 \pm 1.89$ \\
\hline $\begin{array}{c}\text { Bananal Inlet } \\
\text { Mar/2001 }\end{array}$ & $4.08 \pm 0.15$ & $0.51 \pm 0.12$ & $3.16 \pm 0.32$ & $0.88 \pm 0.19$ & $8.63 \pm 0.36$ & $1.16 \pm 0.37$ & $7.44 \pm 2.39$ \\
\hline Itapuca Stone & $2.80 \pm 0.47$ & $0.34 \pm 0.06$ & $2.42 \pm 0.77$ & $0.89 \pm 0.13$ & $6.45 \pm 1.80$ & $0.98 \pm 0.32$ & $6.58 \pm 1.39$ \\
\hline $\begin{array}{c}\text { Bananal Inlet } \\
\text { Jun/2001 }\end{array}$ & $1.83 \pm 0.21$ & $0.30 \pm 0.05$ & $3.96 \pm 0.49$ & $0.34 \pm 0.08$ & $6.43 \pm 0.52$ & $0.56 \pm 0.22$ & $11.5 \pm 7.79$ \\
\hline Itapuca Stone & $5.31 \pm 3.71$ & $1.72 \pm 0.15$ & $8.72 \pm 3.64$ & $2.31 \pm 0.52$ & $18.1 \pm 6.76$ & $1.91 \pm 0.54$ & $9.48 \pm 2.12$ \\
\hline $\begin{array}{c}\text { Bananal Inlet } \\
\text { Nov/2001 }\end{array}$ & $0.87 \pm 0.13$ & $0.83 \pm 0.10$ & $4.61 \pm 0.14$ & $1.11 \pm 0.20$ & $7.42 \pm 0.10$ & $1.14 \pm 0.14$ & $6.51 \pm 0.71$ \\
\hline Itapuca Stone & $2.72 \pm 0.10$ & $1.21 \pm 0.06$ & $7.03 \pm 0.18$ & $1.37 \pm 0.31$ & $12.4 \pm 0.15$ & $1.60 \pm 0.10$ & $7.73 \pm 0.39$ \\
\hline $\begin{array}{c}\text { Bananal Inlet } \\
\text { Mar/2002 }\end{array}$ & $2.84 \pm 0.27$ & $0.86 \pm 0.02$ & $8.90 \pm 0.28$ & $1.07 \pm 0.28$ & $13.7 \pm 0.19$ & $1.59 \pm 0.39$ & $8.60 \pm 2.10$ \\
\hline Itapuca Stone & $5.74 \pm 0.76$ & $1.02 \pm 0.08$ & $4.78 \pm 0.11$ & $1.15 \pm 0.36$ & $19.1 \pm 9.2$ & $3.93 \pm 0.47$ & $19.1 \pm 9.2$ \\
\hline $\begin{array}{c}\text { Bananal Inlet } \\
\text { Jun/2002 }\end{array}$ & $1.25 \pm 0.14$ & $0.30 \pm 0.09$ & $4.58 \pm 0.48$ & $0.53 \pm 0.03$ & $10.9 \pm 0.7$ & $2.38 \pm 0.22$ & $20.6 \pm 1.1$ \\
\hline Itapuca Stone & $13.5 \pm 1.67$ & $3.28 \pm 0.28$ & $6.45 \pm 3.66$ & $2.30 \pm 0.18$ & $32.1 \pm 2.7$ & $4.45 \pm 0.82$ & $14.0 \pm 1.1$ \\
\hline $\begin{array}{c}\text { Bananal Inlet } \\
\text { Aug/2002 }\end{array}$ & $1.30 \pm 0.16$ & $0.23 \pm 0.04$ & $3.97 \pm 0.43$ & $0.51 \pm 0.06$ & $8.8 \pm 1.1$ & $1.66 \pm 0.60$ & $17.2 \pm 1.4$ \\
\hline Itapuca Stone & $7.11 \pm 1.60$ & $1.83 \pm 0.38$ & $12.4 \pm 4.66$ & $1.71 \pm 0.51$ & $24.7 \pm 6.74$ & $2.39 \pm 0.66$ & $10.3 \pm 0.5$ \\
\hline $\begin{array}{c}\text { Bananal Inlet } \\
\text { Oct/2002 }\end{array}$ & $0.90 \pm 0.25$ & $0.25 \pm 0.04$ & $2.25 \pm 0.62$ & $1.37 \pm 0.58$ & $6.1 \pm 1.89$ & $0.48 \pm 0.02$ & $12.9 \pm 4.2$ \\
\hline Itapuca Stone & $8.60 \pm 1.84$ & $2.00 \pm 0.07$ & $9.79 \pm 2.09$ & $2.13 \pm 0.55$ & $24.6 \pm 4.48$ & $1.34 \pm 0.09$ & $18.3 \pm 2.7$ \\
\hline $\begin{array}{c}\text { Bananal Inlet } \\
\text { Jan/2003 }\end{array}$ & $0.76 \pm 0.15$ & $0.16 \pm 0.06$ & $1.96 \pm 0.40$ & $1.26 \pm 0.16$ & $5.4 \pm 0.53$ & $0.77 \pm 0.06$ & $7.1 \pm 1.1$ \\
\hline Itapuca Stone & $4.91 \pm 0.55$ & $0.44 \pm 0.07$ & $1.88 \pm 0.43$ & $1.87 \pm 0.33$ & $11.0 \pm 0.76$ & $1.29 \pm 0.29$ & $8.7 \pm 1.2$ \\
\hline $\begin{array}{c}\text { Bananal Inlet } \\
\text { Mar/2003 }\end{array}$ & $1.31 \pm 0.29$ & $0.22 \pm 0.07$ & $2.47 \pm 0.60$ & $2.27 \pm 0.25$ & $8.5 \pm 0.99$ & $0.56 \pm 0.07$ & $15.5 \pm 3.5$ \\
\hline Itapuca Stone & $10.5 \pm 3.69$ & $0.70 \pm 0.34$ & $3.42 \pm 0.24$ & $1.29 \pm 0.52$ & $20.3 \pm 6.23$ & $2.87 \pm 1.20$ & $17.0 \pm 4.8$ \\
\hline $\begin{array}{c}\text { Bananal Inlet } \\
\text { Jun/2003 }\end{array}$ & $3.95 \pm 0.83$ & $0.91 \pm 0.69$ & $3.59 \pm 1.03$ & $0.67 \pm 0.16$ & $11.2 \pm 1.36$ & $1.39 \pm 0.55$ & $17.3 \pm 4.3$ \\
\hline Itapuca Stone & $14.0 \pm 0.81$ & $1.57 \pm 0.15$ & $4.48 \pm 0.37$ & $1.01 \pm 0.12$ & $22.6 \pm 1.53$ & $1.27 \pm 0.40$ & $22.6 \pm 2.5$ \\
\hline $\begin{array}{c}\text { Bananal Inlet } \\
\text { Aug/2003 }\end{array}$ & $1.46 \pm 0.79$ & $0.43 \pm 0.03$ & $2.10 \pm 0.17$ & $0.36 \pm 0.08$ & $5.5 \pm 2.25$ & $0.75 \pm 0.71$ & $15.1 \pm 5.2$ \\
\hline Itapuca Stone & $8.96 \pm 0.52$ & $1.72 \pm 0.07$ & $6.24 \pm 0.73$ & $0.79 \pm 0.09$ & $18.6 \pm 0.51$ & $0.81 \pm 0.03$ & $23.6 \pm 2.4$ \\
\hline $\begin{array}{c}\text { Bananal Inlet } \\
\text { Nov/2003 }\end{array}$ & $1.44 \pm 1.17$ & $0.29 \pm 0.03$ & $1.93 \pm 0.23$ & $0.39 \pm 0.08$ & $4.9 \pm 1.67$ & $0.63 \pm 0.31$ & $13.5 \pm 6.7$ \\
\hline Itapuca Stone & $10.6 \pm 1.30$ & $3.04 \pm 0.73$ & $11.1 \pm 4.18$ & $2.41 \pm 0.54$ & $28.0 \pm 4.5$ & $1.65 \pm 0.35$ & $11.8 \pm 0.8$ \\
\hline $\begin{array}{c}\text { Bananal Inlet } \\
\text { Feb/2004 }\end{array}$ & $2.12 \pm 0.54$ & $0.58 \pm 0.07$ & $1.91 \pm 0.14$ & $0.69 \pm 0.23$ & $7.3 \pm 1.1$ & $1.34 \pm 0.37$ & $11.6 \pm 4.7$ \\
\hline Itapuca Stone & $3.73 \pm 0.59$ & $0.72 \pm 0.15$ & $1.39 \pm 0.70$ & $1.36 \pm 0.31$ & $18.3 \pm 3.25$ & $6.25 \pm 1.68$ & $14.3 \pm 5.0$ \\
\hline Bananal Inlet & $1.87 \pm 0.80$ & $0.47 \pm 0.06$ & $1.89 \pm 0.80$ & $0.50 \pm 0.16$ & $6.5 \pm 0.6$ & $1.15 \pm 0.27$ & $14.5 \pm 6.1$ \\
\hline
\end{tabular}



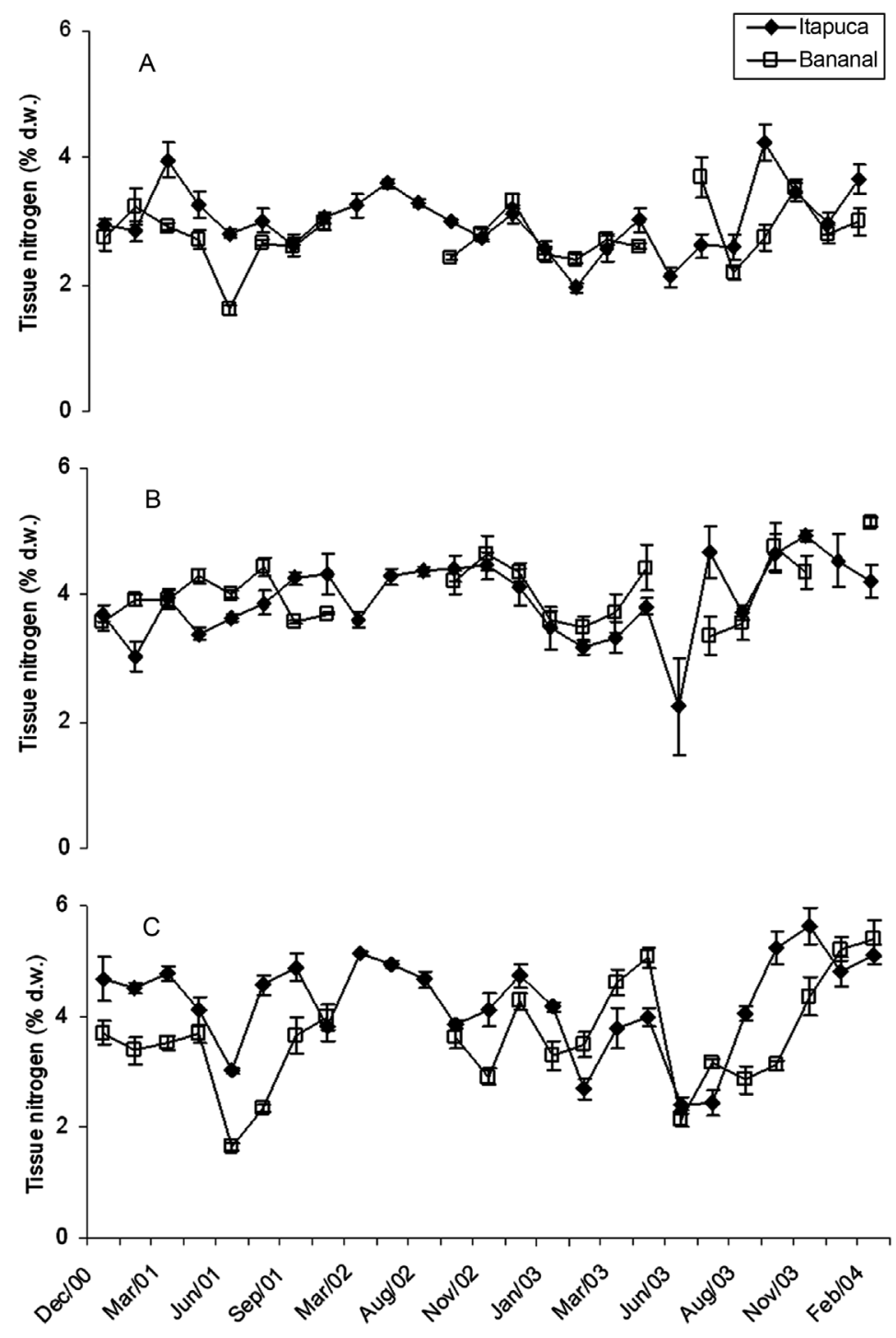

Figure 2. Temporal fluctuations in tissue nitrogen of Chaetomorpha antennina (A), Gymnogongrus griffthisiae (B), and Ulva fasciata (C) sampled in Itapuca Stone and Bananal Inlet from December 2000 to February 2004. Data are expressed as percentage of the dry weight (d.w.) and each point represents the mean of four replicates \pm standard deviation $(n=4)$.

no apparent link with events such as heavy storms or windy conditions in previous days to the field trip. Garbage in the area seems to result from peculiar patterns of circulation in the Inlet, since no local source of pollution exists in the site itself. As one admits the transport of solid garbage from adjacent areas to the Inlet, it is presumable to assume that dissolved nutrients from surrounding eutrophic waters could achieve the Inlet. Nevertheless, it is important to reinforce that in general the seawater in the Inlet is predominantly clean and transparent. Moreover, the Inlet has a remarkable wave action, a factor that contributes for a quick dilution of substances and transport of materials, establishing a presumably low residence time in the Inlet.

A third hypothesis is the occurrence of some upwelling events in coastal areas of Niterói municipality. These events frequently reach Bananal Inlet in summer, but rarely could reach Itapuca Stone (located inside Guanabara Bay). For instance, in one of the filed trips (January 9th, 2004) waters of $17^{\circ} \mathrm{C}$ reached the Inlet (Table 2), a typical temperature of upwelling events in the region. This interpretation is reinforced by the detection of high concentrations of nitrate in that month in the Inlet $(3.39 \pm 0.83 \mu \mathrm{M})$, which were not statistically different of those detected in Itapuca Stone. 

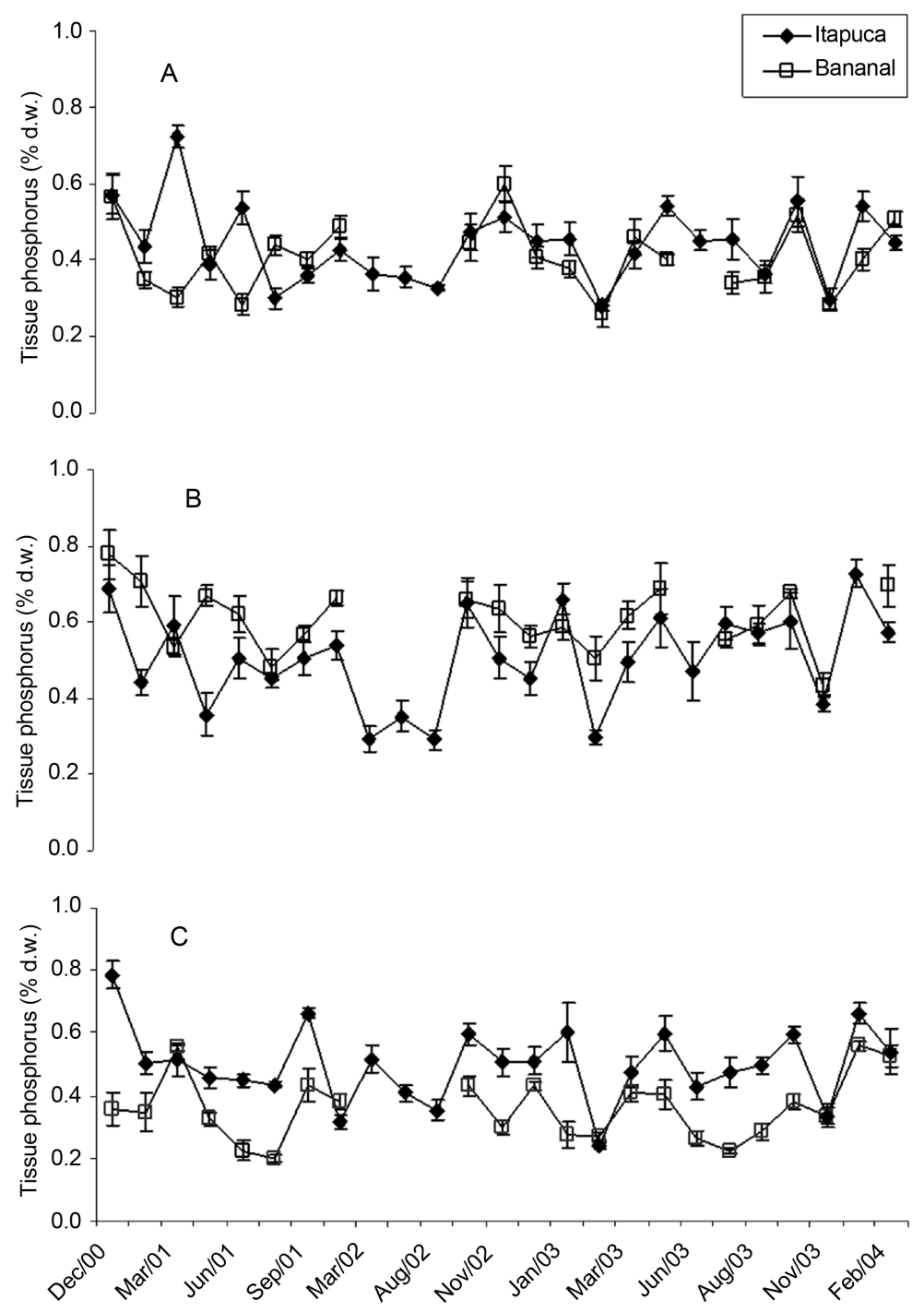

Figure 3. Temporal fluctuations in tissue phosphorus of C. antennina (A), G. griffthisiae (B), and U. fasciata (C) sampled in Itapuca Stone and Bananal Inlet from December 2000 to February 2004. Data are expressed as percentage of the d.w. and each point represents the mean of four replicates $\pm \operatorname{SD}(n=4)$.

The excess of nutrients in Guanabara Bay characterizes that environment as eutrophic [30], achieving hypereutrophy in some parts and generating relevant floristic changes. A small number of macroalgal species exists near the entrance of Guanabara Bay, where Itapuca Stone is located. According to Taouil \& Yoneshigue [45], there are only 45 species in that area, while more than 70 species were recorded in the same site by the end of the decade of 1960. This number contrasts with the 92 species found by Moreira (unpublished data) in Bananal Inlet. The ongoing process of eutrophication has been promoting a loss of biodiversity in Guanabara Bay, changing the characteristics of local algal communities [45]. Opportunistic species, which tolerate high concentrations of pollutants (generally present in large volumes in environments disturbed by cultural eutrophication) tend to proliferate, occupying the space left by more sensitive species [46].

Despite significant differences in the concentrations of dissolved nutrients have been detected in the sites, N:P ratio tended to be similar at the sampling sites throughout the study. An overall mean value of 14.9:1 was calculated for Itapuca Stone and 14.7:1 for Bananal Inlet. Compared to the classical studies [47] [48], which indicate a N:P ratio of 16:1 as an average value for world oceans, the current results are within fluctuations expected for field data. Despite the small number of samples analyzed, values around 15:1 would not indicate limitation by 

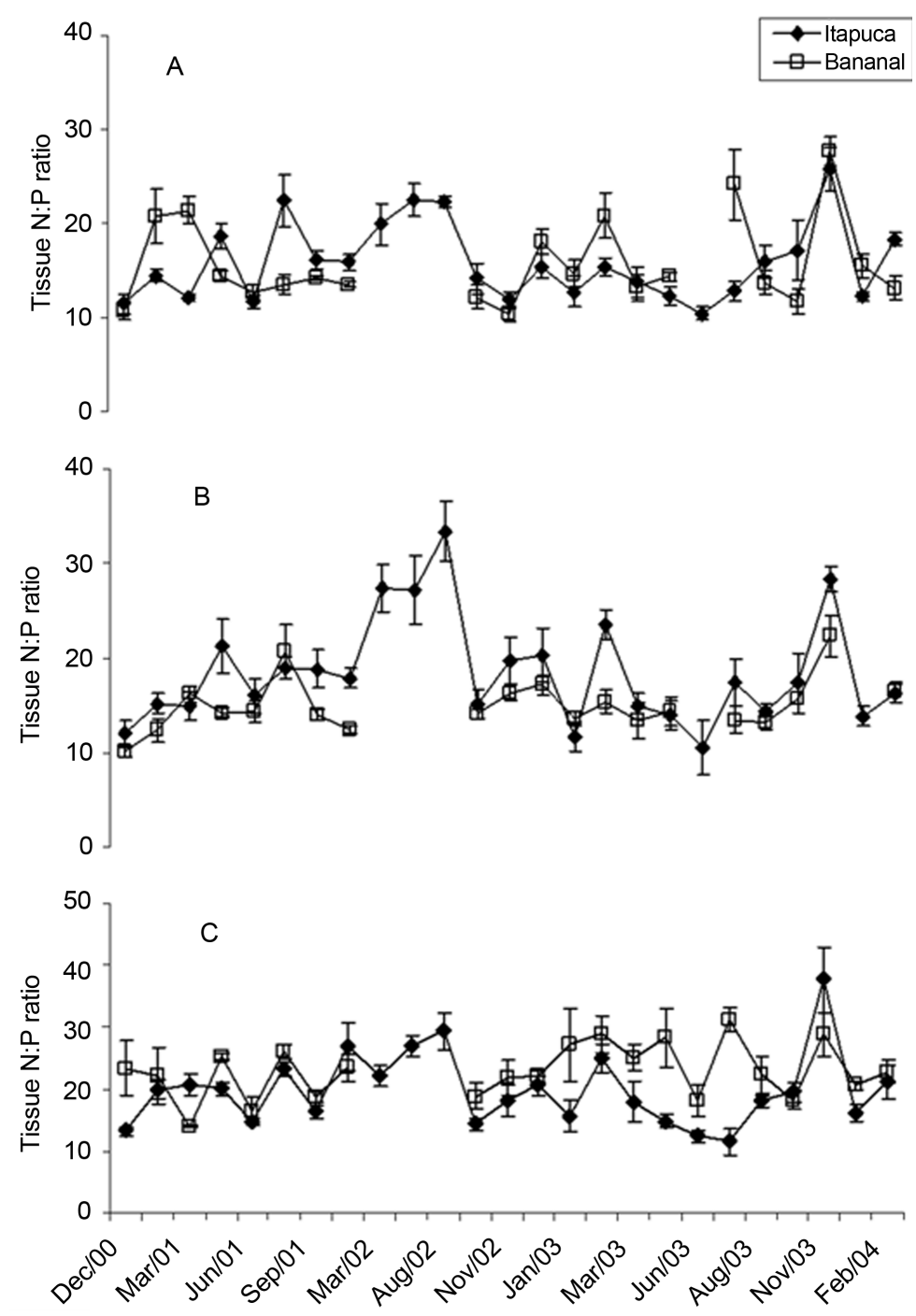

Figure 4. Temporal fluctuations in tissue N:P ratio of C. antennina (A), G. griffthisiae (B), and $U$. fasciata (C) sampled in Itapuca Stone and Bananal Inlet from December 2000 to February 2004. Data are expressed as percentage of the d.w. and each point represents the mean of four replicates \pm SD $(n=4)$.

$\mathrm{N}$ or $\mathrm{P}$ to the algae. This trend contrasts with other Brazilian studies. For instance, Aidar et al. [49] obtained an average N:P ratio of 12:1 for the continental shelf of Ubatuba, São Paulo State, suggesting a phytoplankton limitation by nitrogen. Valentin et al. [30] found wide variations in atomic ratios in different sampling sites in inner parts of Guanabara Bay with a remarkable influence of the tidal regime. Low N:P rations in inner parts of Guanabara Bay $(<10: 1)$ were interpreted as a result of excess phosphate from domestic effluents [30].

Measurements of N:P ratio are insufficient to determine the presence or absence of a given species in an environment under strong impact. It is widely known that each species has an optimal N:P ratio for its metabolic demands [7] [50], but it is unlike to happen competitive exclusion due to this factor. The exclusion of a given species from a disturbed environment by anthropic action is more likely to be a consequence of the effects of pollutants, but normally it is very difficult to determine the limits for the action of a specific pollutant since in general complex mixtures are discharged into the sea [51].

\subsection{Total Tissue Nitrogen and Phosphorus in the Seaweeds}

In this study, the red alga G. griffithsiae tended to show higher concentrations of tissue nitrogen and phosphorus 

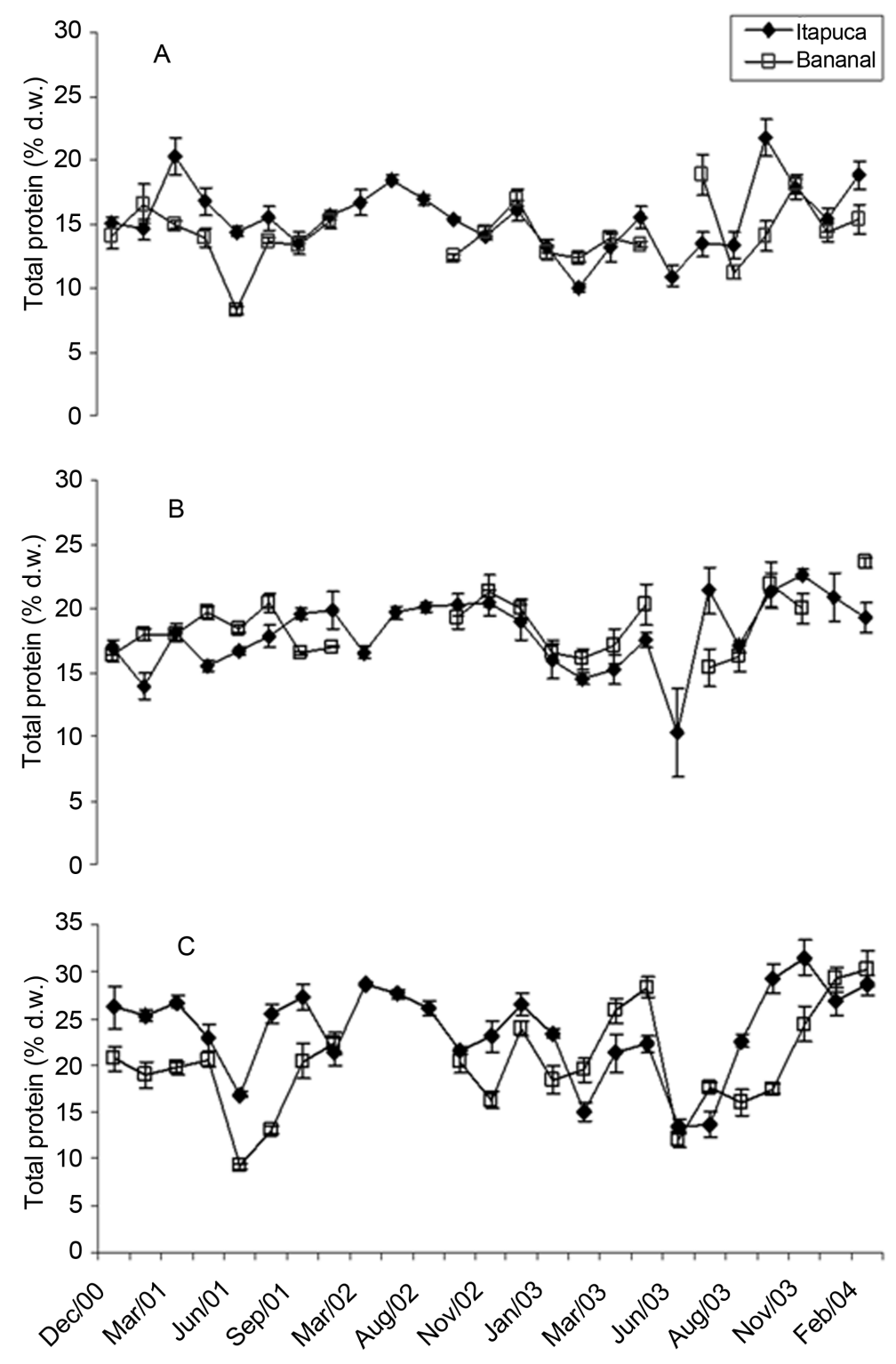

Figure 5. Temporal fluctuations in total protein content of C. antennina (A), G. griffthisiae (B), and U. fasciata (C) sampled in Itapuca Stone and Bananal Inlet from December 2000 to February 2004. Data are expressed as percentage of the d.w. and each point represents the mean of four replicates $\pm \operatorname{SD}(n=4)$.

than the green algae. This is in accordance with studies of Diniz et al. [52] and Lourenço et al. [34] who characterized the chemical composition of seaweeds from Brazilian coastal environments. Rhodophytes tended to show more nitrogen-bearing pigments and higher concentrations of hydrosoluble protein. Higher concentrations of phosphorus in seaweeds would be related to the characteristics of fast growing species, which produce more ATP [7] [52].

In physiological terms, seaweeds from tropical environments show a low demand for dissolved nutrients, compared to seaweeds from temperate environments [53] [54]. In the tropics plants are commonly saturated with nutrients even in low concentrations (e.g.: $3.0 \mu \mathrm{M}$ for $\mathrm{N}$ e $0.25 \mu \mathrm{M}$ for P), which are sufficient to generate high growth rates and tissue nutrients in suitable concentrations. Compared to phytoplankton, seaweeds have a high procurement for carbon, higher than the relative demand for nitrogen and phosphorus, a characteristic related to the life cycles, life span, growth and composition of the thalli [55]. If the availability of inorganic nutrients increases temporarily, there is a natural trend of a fast up take and assimilation of nutrients, displaying in 

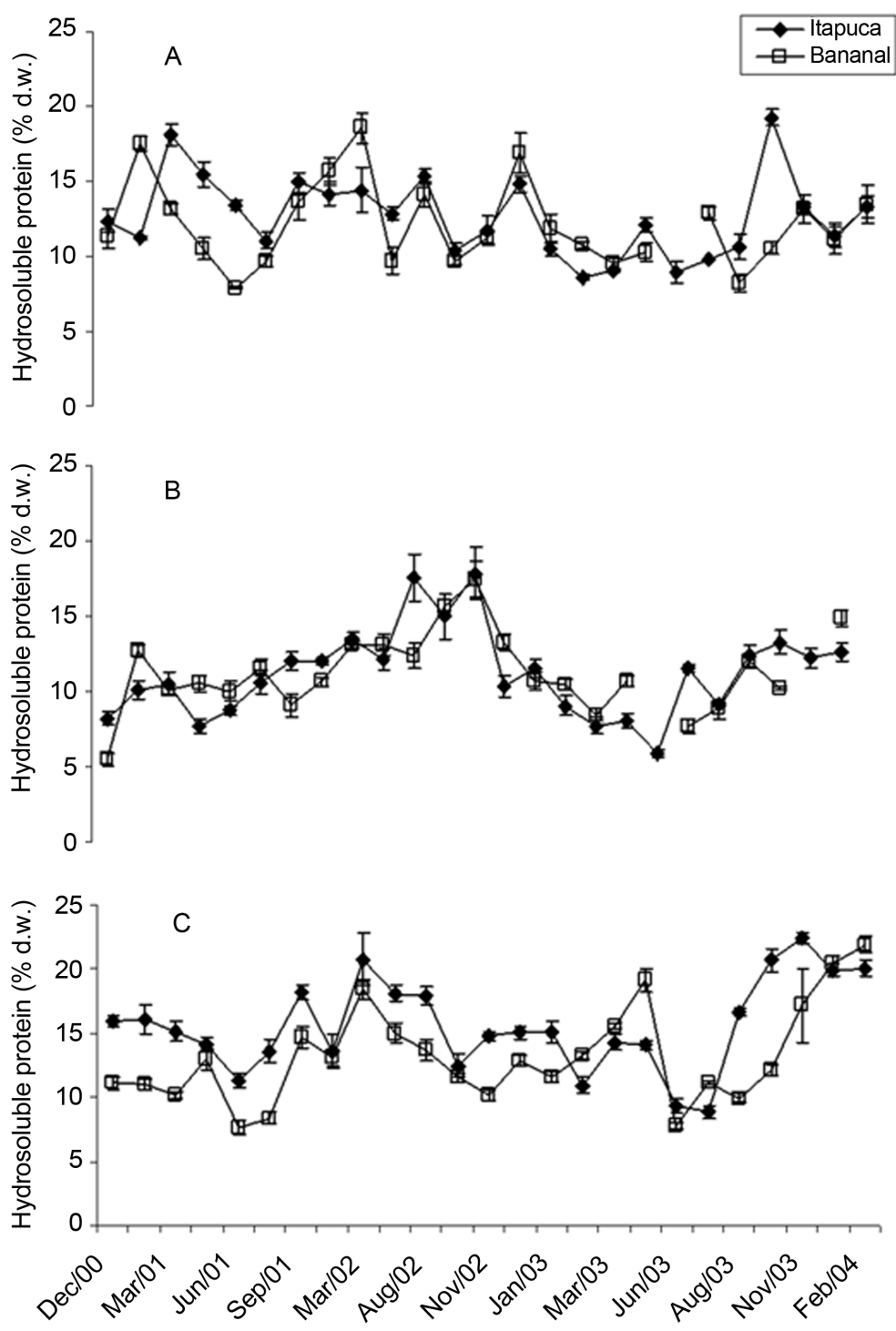

Figure 6. Temporal fluctuations in hydrosoluble protein of C. antennina (A), G. griffthisiae (B), and U. fasciata (C) sampled in Itapuca Stone and Bananal Inlet from December 2000 to February 2004. Data are expressed as percentage of the d.w. and each point represents the mean of four replicates \pm SD $(n=4)$.

the thalli higher concentrations of $\mathrm{N}$ and $\mathrm{P}$ [56]. However, if an abundant amount is kept for a longer period, there is a trend of saturation of the thalli with nutrients, and no increment in algal responses to nutrients is recorded [53]. Thus, an excess of nutrient in water not necessarily will generate high concentrations of $\mathrm{N}$ and $\mathrm{P}$ in tissues, because even a luxuriant consumption of nutrients (such as nitrogen) has a limit, without a progressively linear response to the stimulus after a given point. If high concentrations of nutrients persist, the algae (macroand micro-algae) may either excrete inorganic nutrients or keep the synthesis of organic matter in stable levels, without increases in concentrations of $\mathrm{N}$ - and P-bearing-substances [7] [12] [57]. These are typical responses of algae in eutrophic environments.

In Bananal Inlet, concentrations of dissolved nutrients are supposedly enough to sustain an optimum growth in the species tested. The observations of the local species showed tissue- $\mathrm{N}$ concentrations never lower than $2 \%$ d.w., suggesting that growth conditions would be suitable throughout the year [58]. Thus, the seaweeds tend to show high tissue $\mathrm{N}$ and $\mathrm{P}$ concentrations, possibly close to the saturation level. In this context, measurements done with samples from Bananal Inlet tended to be predominantly high, similar to those of Itapuca Stone. 

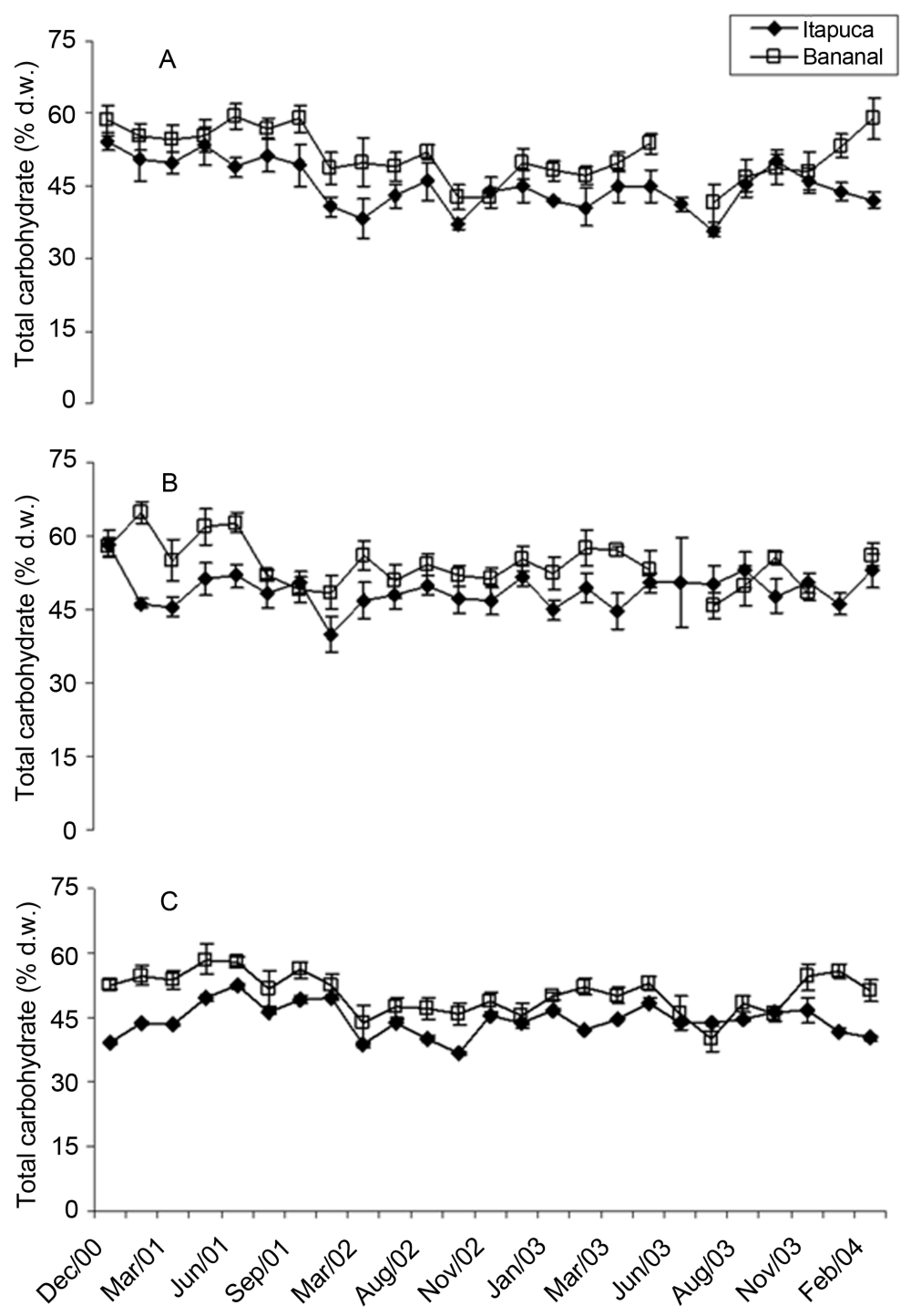

Figure 7. Temporal fluctuations in total carbohydrate of C. antennina (A), G. griffthisiae (B), and U. fasciata (C) sampled in Itapuca Stone and Bananal Inlet from December 2000 to February 2004. Data are expressed as percentage of the d.w. and each point represents the mean of four replicates $\pm \operatorname{SD}(n=4)$.

Another factor to contribute to diminish differences of tissue $\mathrm{N}$ and $\mathrm{P}$ measured in the different sites are topographical features. Itapuca Stone is plan, with low natural shelters (e.g. crevices in rocks), and seaweeds are directly exposed to dryness during low tides. This condition promotes a strong stress in the species, which is expressed as damages in the thalli and loss of tissue nutrients [59] [60]. In many field trips in summer months and also in short isolated periods of strong heat in any season, several individuals showed tips bleached, indicating loss of their constituents. This phenomenon was particularly common in G. griffithsiae, especially easy to see due the contrast between the dark red of the healthy individuals and the pale color (white or yellowish) of damaged plants. In Bananal Inlet this phenomenon was less common, although in some occasions algae were found with bleaching especially after period of strong heat. There, $U$. fasciata was the species that showed more commonly damaged thalli, while G. griffithsiae has never been found with bleaching in Bananal Inlet. This trend is possibly a consequence of the specific occupation of the space by the red alga in Bananal Inlet, always in specific places sheltered from sunshine, under shadows created by large rocks and crevices. These arguments are important to understand why concentrations of tissue N and P of G. griffithsiae were similar in both environments (Figure 2 and Figure 3) and how abiotic sources of stress may influence the nutrient composition of the algae. 

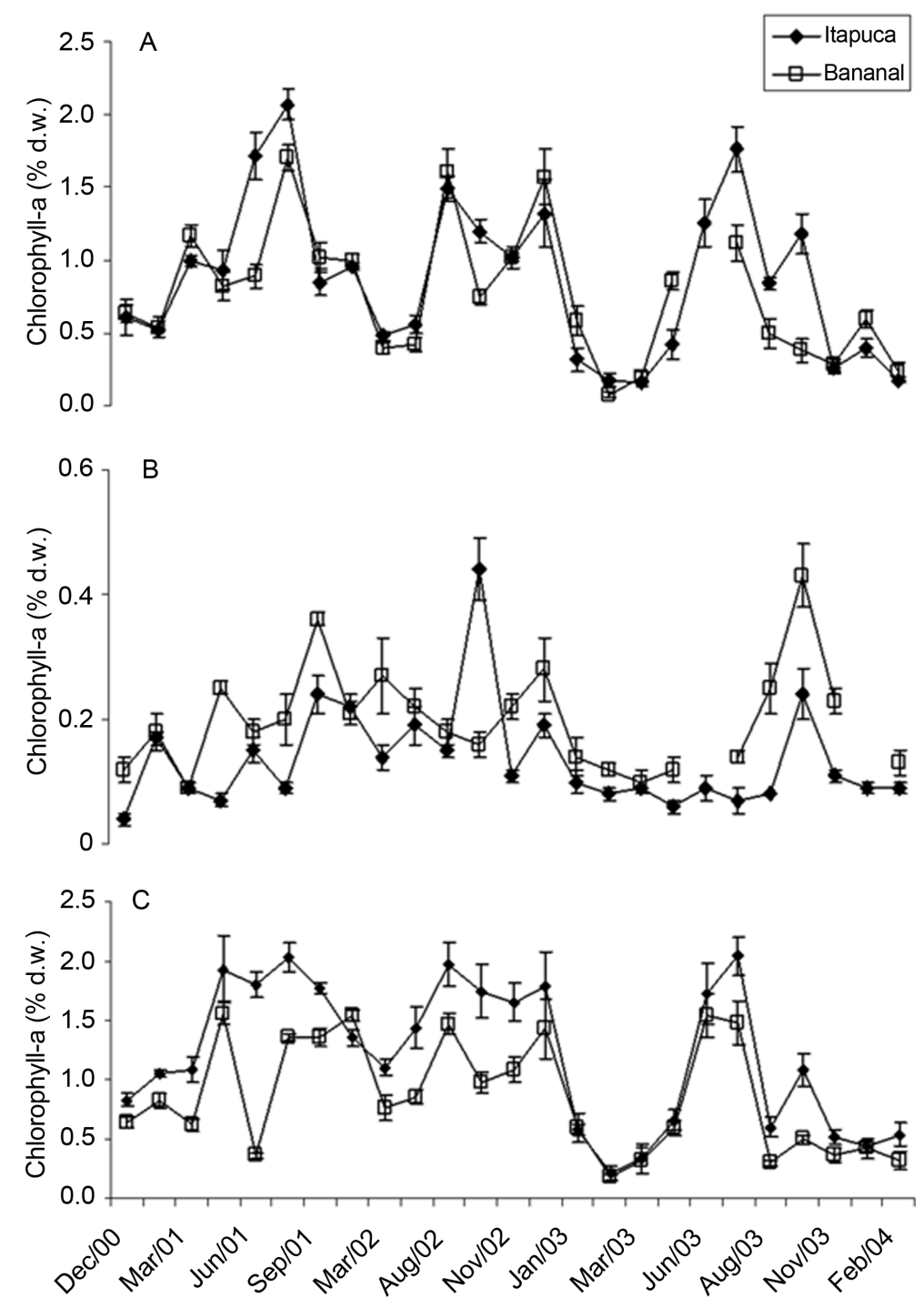

Figure 8. Temporal fluctuations in chlorophyll $a$ content of C. antennina (A), G. griffthisiae (B), and $U$. fasciata (C) sampled in Itapuca Stone and Bananal Inlet from December 2000 to February 2004. Data are expressed as percentage of the d.w. and each point represents the mean of four replicates \pm SD $(n=4)$.

Despite the minor differences in tissue $\mathrm{N}$ and $\mathrm{P}$ for each species in both sites, most of the observations did not reveal cyclic patterns of variation of concentrations, except for lower values of chlorophyll $a$ and total carotenoid in summer/early autumn, contrasting with typical results reported for temperate environments [5] [8]. Fluctuations found in tropical environments are associated to significant changes in concentrations of nutrients throughout the year (including possible inputs of nutrients into the system) or the occurrence of a more intense environmental factor (eg.: temperature, upwelling), affecting algal responses during part of the annual cycle. In a related study, Lourenço et al. [15] studied the seasonal variations of tissue $\mathrm{N}$ and $\mathrm{P}$ of eight macroalgal species of Araruama Lagoon, a hypersaline environment in Rio de Janeiro State. Remarkable seasonal variations in tissue nutrients for the seaweeds were found, with higher values in autumn and lower in spring for most of the species. The authors also considered that seaweeds are severely affected by high temperatures, at least in part of the spring and in the summer. The absence of patterns for seasonal variations in tissue $\mathrm{N}$ and $\mathrm{P}$ of the seaweeds in the present study suggests: (i) that the nutrient supply is virtually constant or it suffers minor variations; and (ii) that other abiotic factors (e.g. temperature) play a secondary role to influence nutrient accumulation by the seaweeds. The lack of seasonal variations of tissue $\mathrm{N}$ and $\mathrm{P}$ of 10 seaweeds (6 green and 4 red algae) was also 

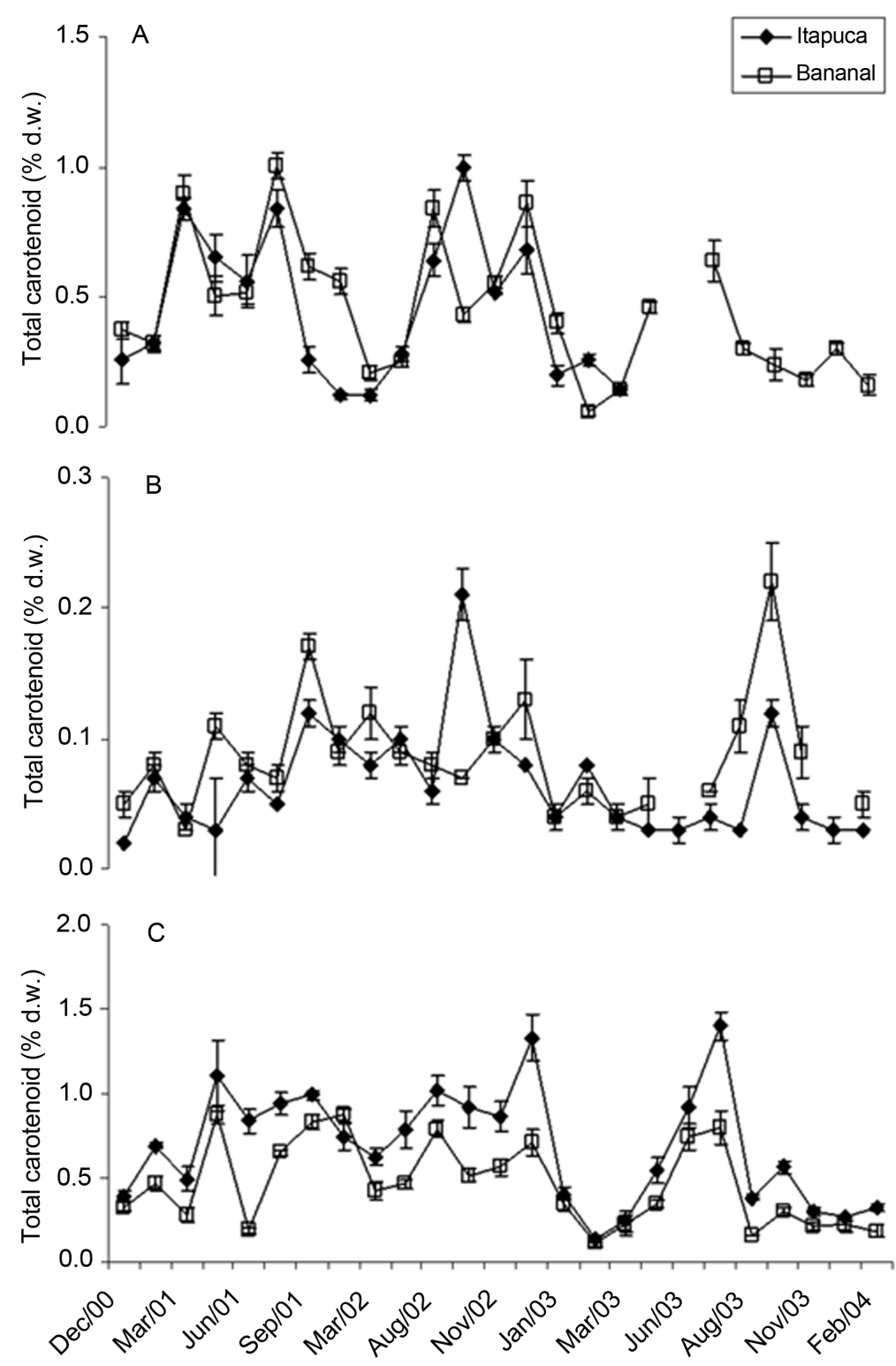

Figure 9. Temporal fluctuations in total carotenoid content of C. antennina (A), G. griffthisiae (B), and $U$. fasciata (C) sampled in Itapuca Stone and Bananal Inlet from December 2000 to February 2004. Data are expressed as percentage of the d.w. and each point represents the mean of four replicates \pm SD $(n=4)$.

confirmed [56] in a seven-year study (from 1997 to 2004) performed in Boa Viagem Beach, a site located in Guanabara Bay. Lourenço et al. [28] found N:P atomic ratios in the algal tissues typically higher than 20:1 and lower phosphorus concentrations in the water than at Itapuca Stone in the present study.

According to the Björnsäter and Wheeler's classification [61] of macroalgal nutrient status based on N:P ratio of tissues, a N:P ratio $<16$ indicates N-limitation; a N:P ratio $16-24$ indicates N-sufficiency and P-sufficiency -i.e. no limitation and N:P $>24$ indicates P-limitation. Applying this classification to our data we could conclude that the macroalgae in the sampling sites are permanently $\mathrm{N}$ - and P-sufficient, with few exceptions. However, the N:P ratio must be evaluated with care, as it may obscure trends for the individual elements. For instance, the lower values for phosphorus in the seaweeds were normally $>0.40 \% \mathrm{~d}$.w. A $0.40 \%$ of tissue P does not represent a low level of phosphorus, and it is actually higher than values found for many other algae from tropical environments [53] [54]. In some cases a high N:P ratio observed may be strongly affected by the high 
concentrations of nitrogen and is not necessarily indicative of P limitation. Thus, the classification of Björnsäter \& Wheeler [61] must be considered with caution, because the ranges may not be suitable for macroalgae from tropical environments such as Guanabara Bay and Bananal Inlet. Further investigations are needed to test the suitability of that classification for tropical environments, where seaweeds typically grow well with low concentrations of dissolved nutrients and normally have lower tissue $\mathrm{N}$ and $\mathrm{P}$ compared to species from temperate environments.

\subsection{Protein, Carbohydrate and Photosynthetic Pigments}

Following the same general trends described for total nitrogen, the red alga G. griffithsiae tended to show higher concentrations of hydrosoluble protein than the green algae. Our results also agree with those of Gressler et al. [62], who found that four red seaweeds from Brazil typically show hydrosoluble protein fluctuating from $4.6 \%$ to $18.3 \%$ of d.w. In our study, hydrosoluble protein of G. griffithsiae fluctuates from $10 \%$ to $20 \%$ of d.w in most of the observations.

Possibly most of the studies on major chemical components of seaweeds have focus on the nutritional properties of the species, e.g. [63]-[69]. However, analyses of major chemical components are important tools for environmental issues. Previous studies performed confirm that tissue protein is positively correlated dissolved nitrogen in the water [70] [71]. In the present study, the apparent permanent sufficiency on nutrients (especially nitrogen) would contribute to the high measurements of protein in the seaweeds in both sites. One can speculate that in Itapuca Stone the saturating levels of dissolved nutrients would keep protein in high concentrations. Despite the concentration of nutrients is not so high at Bananal Inlet it would be enough to generate a high accumulation of protein. These interpretations have support from the studies of [53] with the green alga Enteromorpha intestinalis (=Ulva intestinalis) in mesocosms, in which the alga did not respond to enrichment with nutrients if thalli concentrations were saturated.

The accumulation of protein tends to promote a decrease in carbohydrate production. The assimilation of nitrogen (ammonia) into amino acids occurs via a GS/GOGAT (glutamine sintetase/glutamine: 2-oxoglutarate aminotransferase) system, resulting in production of glutamate. For the synthesis of glutamate two molecules of 2-oxiglutarate are required, while for the synthesis of other amino acids carbon skeletons are required through respiratory chain. As a result, assimilation photosynthetic nitrogen stimulates the respiratory flux of carbon. In cells growing with high concentrations of nutrients, levels of endogenous reserves of carbohydrate drop and the assimilation of nitrogen in amino acids depends on recent photosynthesis [10] [72].

These arguments support the occurrence of higher concentrations of carbohydrate in samples from Bananal Inlet, especially G. griffithsiae and U. fasciata. Results for G. griffithsiae are similar to those of Perfeto [73], who found values predominantly $>50 \%$ d.w. for the same species in a seasonal study in southern Brazil, under subtropical climate. Pádua et al. [24] also reported similar results for total carbohydrate, with concentrations varying from 55.3\% to 58.4\% of d.w. for Ulva lactuca and U. fasciata from Paraná State, Brazil. Protein levels measured in those species by the same authors varied from $13.3 \%$ to $18.4 \%$ d.w. [24]; these values are slightly lower than the current results. Higher concentrations of carbohydrate than that of protein in 30 common seaweeds of tropical Australia were also found [74], as well as for three common species of Abu Qir Bay, Egipt [75]. Despite the amount of dissolved nutrients in Bananal Inlet is relatively high, it is lower than in Itapuca Stone. Considering the coupling between carbon and nitrogen metabolism, it is logical to understand a tendency for more carbohydrate in Bananal Inlet, even with discrete differences in some comparisons. As C. antennina exhibited the smallest differences for virtually all comparisons of the two sites, this alga probably has a naturally low demand for nutrients. Supposedly the chemical composition of $C$. antennina was virtually not affected by differences in nutrient regimes in the sites. This trend has been documented for slow-growing tropical macroalgae, such as thus of the genus Sargassum [54] and green algae typical of warm waters, such as Halimeda [53]. Thus, independent of specific environmental characteristics in which they are, these species tend to exhibit discrete responses of synthesis of substances to available nutrients, keeping their chemical composition with slight fluctuations.

A wide range of variation in the content of hydrosoluble protein in the green algae U. fasciata and C. antennina agrees with the variations in tissue nitrogen throughout time, with accumulation of nitrogen in some periods as protein. The occurrence of very "flexible" protein content in those seaweeds points to the capability of them to respond to rapid environmental changes. Fleurence [76] points that protein contents in Ulva typically vary from $10 \%$ to $26 \%$ d.w. 
The high concentrations of total carotenoid found in this study (normally higher than $50 \%$ of the chlorophyll content) points to the role of carotenoids as shields to protect the photosystems [77]. The presence of different quantities and kinds of pigments (chlorophyll, carotenoids, phycoerythrin) in G. griffithsiae results in a high capacity to absorb light in virtually all visible light. The diverse pigments of the red alga may favor the species to occupy microhabitats not directly exposed to light in rocky shores, under shadows of large rocks or in crevices. G. griffithsiae is found in these microhabitats at Bananal Inlet. In this context, the species could have competitive advantages for not exposing itself to high intensities of light. Presumably, G. griffithsiae shows an efficient apparatus for light absorption. The presence of accessory pigments could account for the lower concentrations of chlorophyll in G. griffithsiae compared to the other species.

Remarkable oscillations in pigment content were recorded in Ulva fasciata and they seem to be related to the loss of pigments in certain periods of the year, as a consequence of partial loss of thalli due to excessive desiccation. Intertidal seaweeds experience extreme conditions of heat in tropical environments, which may affect their morphological features [78]. As a foliose alga that occupies the mid-littoral area, U. fasciata is particularly exposed to high temperatures. This factor is apparently less important in C. antennina, which inhabits places under direct wave action and permanently in contact with seawater in movement. Moreover, arguments relative to life cycle of the species (not assessed in this study) are also potentially relevant, especially for $U$. fasciata, which suffers a population decline in summer due to phenological processes in the region [51]. The apparent biomass fluctuations observed for $U$. fasciata (with lower biomass in summer) were similar in both environments, suggests that abiotic factors such as light and temperature might be as important as dissolved nutrients to affect the chemical composition of the species, as demonstrated for Gracilaria tikvahiae [59]. Gymnogongrus griffithsiae also presented significant changes in the concentrations of photosynthetic pigments (less than $U$. fasciata) and loss of thalli in samples collected at Itapuca Stone, after periods of strong heat. The exposure of seaweeds to high irradiation in summer could account for the lower contents of chlorophyll recorded for G. griffithsiae and $U$. fasciata due to loss of tissues. Aguilera et al. [14] recorded this same trend for Porphyra umbilicalis from the North Sea, with loss of chlorophyll after periods of intense heat.

\section{Concluding Remarks}

Changes in the concentrations of total protein, hydrosoluble protein, total carbohydrate, chlorophyll $a$, total carotenoid, tissue nitrogen and tissue phosphorus in Chaetomorpha antennina, Gymnogongrus griffithsiae and Ulva fasciata were predominantly small or absent in the two sampling sites. No clear cyclic variations throughout time were detected for the substances measured in the seaweeds, except for pigments, which showed declines at the end of summer months. Dissolved nutrients are available in higher concentrations to seaweeds at Itapuca Stone, where they possibly achieve permanent saturating levels for the seaweeds. Concentrations of dissolved nitrogen and phosphorus at Bananal Inlet seem to be always high enough to supply the metabolic demands of the seaweeds for synthesis of organic substances and growth, with no evidence of nutrient limitation throughout the year.

\section{Acknowledgements}

We are indebted to FAPERJ (Rio de Janeiro State Research Support Foundation) for the financial support to this study. We acknowledge Dr Aguinaldo N. Marques Júnior for offering us laboratory facilities. The authors are grateful to Leonardo de Souza (deceased), Amanda P. de Freitas, Frederico A. Herdy, Rodrigo R. Machado, Giselle S. Costard, Rachel S. Guanabara, Marcello T. Carvalho, and Joana N.P. Freitas their assistance in field trips and in laboratory analyses. We thank Dr. Maria Teresa M. de Széchy, Dr. Ricardo Coutinho and Dr. Roberto C. Villaça for their critical comments on the early draft of this study (in Portuguese).

\section{References}

[1] Lapointe, B.E. and Duke, S.C. (1984) Biochemical Strategies for Growth of Gracilaria tikvahiae (Rhodophyta) in Relation to Light Intensity and Nitrogen Availability. Journal of Phycology, 20, 488-495. http://dx.doi.org/10.1111/j.0022-3646.1984.00488.x

[2] Valiela, I., McClelland, J., Hauxwell, J., Behr, P.J. and Foreman, K. (1997) Macroalgal Blooms in Shallow Estuaries: Controls and Ecophysiological and Ecosystem Consequences. Limnology and Oceanography, 42, 1105-1118.

http://dx.doi.org/10.4319/lo.1997.42.5_part_2.1105 
[3] Rivers, J.S. and Peckol, P. (1995) Interactive Effects of Nitrogen and Dissolved Inorganic Carbon on Photosynthesis, Growth, and Ammonium Uptake of the Macroalgae Cladophora vagabunda and Gracilaria tikvahiae. Marine Biology, 121, 747-753. http://dx.doi.org/10.1007/BF00349311

[4] Fong, P., Donohoe, R.M. and Zedler, J.B. (1994) Nutrient Concentration in Tissue of the Macroalga Enteromorpha as a Function of Nutrient History: An Experimental Evaluation Using Field Microcosms. Marine Ecology Progress Series, 106, 273-281. http://dx.doi.org/10.3354/meps106273

[5] Wheeler, P.A. and Björnsäter, B.R. (1992) Seasonal Fluctuations in Tissue Nitrogen, Phosphorus, and N:P for Five Macroalgal Species Common to the Pacific Northwest Coast. Journal of Phycology, 28, 1-6. http://dx.doi.org/10.1111/j.0022-3646.1992.00001.x

[6] Villares, R. and Carballeira, A. (2003) Seasonal Variation in the Concentrations of Nutrients in Two Green Macroalgae and Nutrient Levels in Sediments in the Rias Baixas (NW Spain). Estuarine, Coastal and Shelf Science, 58, 887-900. http://dx.doi.org/10.1016/j.ecss.2003.07.004

[7] Lobban, C.S. and Harrison, P.H. (1994) Seaweed Ecology and Physiology. Cambridge University Press, New York. http://dx.doi.org/10.1017/CBO9780511626210

[8] Peckol, P., DeMeo-Andersen, B., Rivers, J., Valiela, I., Maldonado, M. and Yates, J. (1994) Growth, Nutrient Uptake Capacities and Tissue Constituents of the Macroalgae Cladophora vagabunda and Gracilaria tikvahiae Related to Site-Specific Nitrogen Loading Rates. Marine Biology, 121, 175-185. http://dx.doi.org/10.1007/BF00349487

[9] Kamer, K., Fong, P., Kennison, R. and Schiff, K. (2004) Nutrient Limitation of the Macroalga Enteromorpha intestinalis Collected along a Resource Gradient in a Highly Eutrophic Estuary. Estuaries, 27, 201-208. http://dx.doi.org/10.1007/BF02803377

[10] Turpin, D.H. (1991) Effects of Inorganic N Availability on Algal Photosynthesis and Carbon Metabolism. Journal of Phycology, 27, 14-20. http://dx.doi.org/10.1111/j.0022-3646.1991.00014.x

[11] Bird, K.T., Habig, C. and DeBusk, T. (1982) Nitrogen Allocation and Storage Patterns in Gracilaria tikvahiae (Rhodophyta). Journal of Phycology, 18, 344-348. http://dx.doi.org/10.1111/j.1529-8817.1982.tb03194.x

[12] Lourenço, S.O., Barbarino, E., Lavín, P.L., Marquez, U.M.L. and Aidar, E. (2004) Distribution of Intracellular Nitrogen in Marine Microalgae: Calculation of New Nitrogen-to-Protein Conversion Factors. European Journal Phycology, 39, 17-32. http://dx.doi.org/10.1080/0967026032000157156

[13] Dere, S., Dalkiran, N., Karacaoğlu, D., Yildiz, G. and Dere, E. (2003) The Determination of Total Protein, Total Soluble Carbohydrate and Pigment Contents of Some Gemlik-Karacaali (Bursa) and Erdek-Ormanli (Balikesir) in the Sea Marmara, Turkey. Oceanologia, 45, 453-471.

[14] Aguilera, J., Jiménez, C., Figueroa, F.L., Lebert, M. and Häder, D.P. (1999) Effect of Ultraviolet Radiation on Thallus Absorption and Photosynthetic Pigments in the Red Alga Porphyra umbilicalis. Journal of Photochemistry and Photobiology B: Biology, 48, 75-82. http://dx.doi.org/10.1016/S1011-1344(99)00015-9

[15] Lourenço, S.O., Barbarino, E., Nascimento, A. and Paranhos, R. (2005) Seasonal Variations in Tissue Nitrogen and Phosphorus of Eight Macroalgae from a Tropical Hypersaline Coastal Environment. Cryptogamie Algologie, 26, 355-371.

[16] Aitken, K.A., Melton, L.D. and Brown, M.T. (1991) Seasonal Protein Variation in the New Zealand Seaweeds Porphyra columbina Mont. and Porphyra subtumens J. Ag. (Rhodophyceae). Japanese Journal of Phycology, 39, 307-317.

[17] Henley, W.J. and Dunton, K.H. (1995) A Seasonal Comparison of Carbon, Nitrogen, and Pigment Content in Laminaria solidungula and L. saccharina (Phaeophyta) in the Alaskan Artic. Journal of Phycology, 31, 325-331. http://dx.doi.org/10.1111/j.0022-3646.1995.00325.x

[18] Korbee, N., Figueroa, F.L. and Aguilera, J. (2005) Effect of Light Quality on the Accumulation of Photosynthetic Pigments, Proteins and Mycosporine-Like Amino Acids in the Red Alga Porphyra leucosticta (Bangiales, Rhodophyta). Journal of Photochemistry and Photobiology B: Biology, 80, 71-78. http://dx.doi.org/10.1016/j.jphotobiol.2005.03.002

[19] Tabarsa, M., Rezaei, M., Ramezanpour, Z., Waaland, J.R. and Rabiei, R. (2012) Fatty Acids, Amino Acids, Mineral Contents, and Proximate Composition of Some Brown Seaweeds. Journal of Phycology, 48, 285-292. http://dx.doi.org/10.1111/j.1529-8817.2012.01122.x

[20] Madden, M., Mitra, M., Ruby, D. and Schwarz, J. (2012) Seasonality of Selected Nutritional Constituents of Edible Delmarva Seaweeds. Journal of Phycology, 48, 1289-1298. http://dx.doi.org/10.1111/j.1529-8817.2012.01207.x

[21] Polat, S. and Ozogul, Y. (2013) Seasonal Proximate and Fatty Acid Variations of Some Seaweeds from the Northeastern Mediterranean Coast. Oceanologia, 55, 375-391. http://dx.doi.org/10.5697/oc.55-2.375

[22] Schaffelke, B. (1999) Short-Term Nutrient Pulses as Tools to Assess Responses of Coral Reef Macroalgae to Enhanced Nutrient Availability. Marine Ecology Progress Series, 182, 305-310. http://dx.doi.org/10.3354/meps182305

[23] Wong, K.H. and Cheung, C.K. (2001) Nutritional Evaluation of Some Subtropical Red and Green Seaweeds Part II. In 
Vitro Protein Digestibility and Amino Acid Profiles of Protein Concentrates. Food Chemistry, 72, 11-17. http://dx.doi.org/10.1016/S0308-8146(00)00176-X

[24] Pádua, M., Fontoura, P.S.G. and Mathias, A.L. (2004) Chemical Composition of Ulvaria oxysperma (Kützing) Bliding, Ulva lactuca (Linnaeus) and Ulva fasciata (Delile). Brazilian Archives of Biology and Technology, 47, 49-55. http://dx.doi.org/10.1590/S1516-89132004000100007

[25] Devi, G.K., Thirumaran, G., Manivannan, K. and Anantharaman, P. (2009) Element Composition of Certain Seaweeds from Gulf of Mannar Marine Biosphere Reserve; Southeast Coast of India. World Journal of Dairy \& Food Sciences, 4 , 46-55.

[26] Diniz, G.S., Barbarino, E., Oiano-Neto, J., Pacheco, S. and Lourenço, S.O. (2011) Gross Chemical Profile and Calculation of Nitrogen-to-Protein Conversion Factors for Five Tropical Seaweeds. American Journal of Plant Sciences, 2, 287296. http://dx.doi.org/10.4236/ajps.2011.23032

[27] Siddique, M.A.M., Aktar, M. and Khatib, M.A.M. (2013) Proximate Chemical Composition and Amino Acid Profile of Two Red Seaweeds (Hypnea pannosa and Hypnea musciformis) Collected from St. Martin’s Island, Bangladesh. Journal of Fisheries Sciences, 7, 178-186.

[28] Lourenço, S.O., Barbarino, E., Nascimento, A., Freitas, J. and Diniz, G. (2006) Tissue Nitrogen and Phosphorus in Seaweeds in a Tropical Eutrophic Environment: What a Long-Term Study Tells Us. Journal of Applied Phycology, 18, 389-398. http://dx.doi.org/10.1007/s10811-006-9035-9

[29] Mayr, L.M., Tenenbaum, D.R., Villac, M.C., Paranhos, R., Nogueira, C.R., Bonecker, S.L.C. and Bonecker, A.C. (1989) Hydrological Characterization of Guanabara Bay. In: Magoo, O.T. and Neves, C., Eds., Coastlines of Brazil, American Society of Civil Engineering, New York, 129-139.

[30] Valentin, J.L., Tenenbaum, D.R., Bonecker, A.C.T., Bonecker, S.L.C., Nogueira, C.R. and Villac, M.C. (1999) O Sistema Planctônico da Baía de Guanabara: Síntese do Conhecimento. Oecologia Brasiliensis, 7, 35-59. http://dx.doi.org/10.4257/oeco.1999.0701.02

[31] Wynne, M.J. (1998) A Checklist of Benthic Marine Algae of the Tropical and Subtropical Western Atlantic: First Revision. In: Nova Hedwigia, Suppl. 116, J. Cramer in der Gebr. Borntraeger Verlagsbuchhandlung, Stuttgart, 1-155.

[32] Hach, C.C., Bowden, B.K., Kopelove, A.B. and Brayton, S.T. (1987) More Powerful Peroxide Kjeldahl Digestion Method. Journal of the Association of Official Analytical Chemistry, 70, 783-787.

[33] Lowry, O.H., Rosebrough, N.J., Farr, A.L. and Randall, R.L. (1951) Protein Measurement with the Folin Phenol Reagent. The Journal of Biological Chemistry, 193, 265-275.

[34] Lourenço, S.O., Barbarino, E., De-Paula, J.C., Da S. Pereira, L.O. and Lanfer Marquez, U.M. (2002) Amino Acid Com- position, Protein Content, and Calculation of Nitrogen-to-Protein Conversion Factors for Nineteen Tropical Seaweeds. Phycological Research, 50, 233-241. http://dx.doi.org/10.1111/j.1440-1835.2002.tb00156.x

[35] Myklestad, S. and Haug, A. (1972) Production of Carbohydrates by the Marine Diatom Chaetoceros affinis var. willie (Gran) Hustedt. I. Effect of the Concentration of Nutrients in the Culture Medium. Journal of Experimental of Marine Biology and Ecology, 9, 125-136. http://dx.doi.org/10.1016/0022-0981(72)90041-X

[36] DuBois, M., Gilles, K.A., Hamilton, J.K., Rebers, P.A. and Smith, F. (1956) Colorimetric Method for Determination of Sugars and Related Substances. Analytical Chemistry, 28, 350-356. http://dx.doi.org/10.1021/ac60111a017

[37] Lorenzen, C.J. (1967) Determination of Chlorophyll and Pheopigments: Spectrophotometric Equations. Limnology and Oceanography, 12, 343-346. http://dx.doi.org/10.4319/lo.1967.12.2.0343

[38] Strickland, J.D.H. and Parsons, T.R. (1968) A Practical Handbook of Seawater Analysis. Bulletin of Fisheries Research Board of Canada, 167, 1-311.

[39] Parsons, T.R., Maita, Y. and Lalli, C.M. (1984) A Manual of Chemical and Biological Methods for Seawater Analysis. Pergamon Press, Oxford.

[40] Aminot, A. and Chaussepied, M. (1983) Manuel des Analyses Chimiques en Milieu Marin. CNEXO, Brest.

[41] Grasshoff, K., Ehrhardt, M. and Kremling, K. (1983) Methods of Seawater Analysis. Verlag Chemie, Weinheim.

[42] Zar, J.H. (1996) Biostatistical Analysis. 3rd Edition, Prentice Hall, Inc., Upper Saddle River.

[43] Shin, H.W., Sidharthan, M. and Young, K.S. (2002) Forest Fire Ash Impact on Micro- and Macroalgae in the Receiving Waters of the East Coast of South Korea. Marine Pollution Bulletin, 45, 203-209. http://dx.doi.org/10.1016/S0025-326X(02)00156-X

[44] Kjerfve, B., Ribeiro, C.H.A., Dias, G.T.M., Filippo, A.M. and Quaresma, V.S. (1997) Oceanographic Characteristics of an Impacted Coastal Bay: Baía de Guanabara, Rio de Janeiro, Brazil. Continental Shelf Research, 17, 1609-1643. http://dx.doi.org/10.1016/S0278-4343(97)00028-9

[45] Taouil, A. and Yoneshigue-Valentin, Y. (2002) Alterações na Composição Florística das Algas da Praia de Boa Viagem 
(Niterói, RJ). Revista Brasileira de Botânica, 25, 405-412. http://dx.doi.org/10.1590/S0100-84042002012000004

[46] Martínez-Aragón, J.F., Hernández, I., Pérez-Lloréns, J.L., Vázquez, R. and Vergara, J.J. (2002) Biofiltering Efficiency in Removal of Dissolved Nutrients by Three Species of Estuarine Macroalgae Cultivated with Sea Bass (Dicentrarchus labrax) Waste Waters 1.Phosphate. Journal of Applied Phycology, 14, 365-374. http://dx.doi.org/10.1023/A:1022134701273

[47] Redfield, A.C. (1958) The Biological Control of Chemical Factors in the Environment. American Scientist, 46, 205221.

[48] Redfield, A.C., Ketchum, B.H. and Richards, F.A. (1963) The Influence of Organisms on the Chemical Composition of Seawater. In: Hill, M.N., Ed., The Sea, Interscience, New York, 26-77.

[49] Aidar, E., Gaeta, S.A., Giansella-Galvão, S., Kutner, M.B.B. and Teixeira, C. (1993) Ecossistema Costeiro Subtropical: Nutrientes Dissolvidos, Fitoplâncton e Clorofila-a e suas Relações com as Condições Oceanográficas na Região de Ubatuba, SP. Instituto Oceanográfico da USP, 10, 9-43.

[50] Fong, P., Zedler, J.B. and Donohoe, R.M. (1993) Nitrogen vs. Phosphorus Limitation of Algal Biomass in Shallow Coastal Lagoons. Limnology and Oceanography, 38, 906-923. http://dx.doi.org/10.4319/lo.1993.38.5.0906

[51] Teixeira, V.L., Pereira, R.C., Marques Jr., A.N., Leitão Filho, C.M. and Silva, C.A.R. (1987) Seasonal Variations in Infralitoral Seaweed Communities under a Pollution Gradient in Baía de Guanabara, Rio de Janeiro (Brazil). Ciência e Cultura, 39, 423-428.

[52] Diniz, G.S., Barbarino, E. and Lourenço, S.O. (2012) On the Chemical Profile of Marine Organisms from Coastal Subtropical Environments: Gross Composition and Nitrogen-to-Protein Conversion Factors. In: Marcelli, M., Ed., Oceanography, InTech, Rijeka, 297-320. http://dx.doi.org/10.5772/29294

[53] Fong, P., Boyer, K.E., Kamer, K. and Boyle, K.A. (2003) Influence of Initial Tissue Nutrient Status of Tropical Marine Algae on Response to Nitrogen and Phosphorus Additions. Marine Ecology Progress Series, 262, 111-123. http://dx.doi.org/10.3354/meps262111

[54] Hwang, R.L., Tsai, C.C. and Lee, T.M. (2004) Assessment of Temperature and Nutrient Limitation on Seasonal Dynamics among Species of Sargassum from a Coral Reef in Southern Taiwan. Journal of Phycology, 40, 463-473. http://dx.doi.org/10.1111/j.1529-8817.2004.03086.x

[55] Pedersen, M.F. and Borum, J. (1996) Nutrient Control of Algal Growth in Estuarine Waters. Nutrient Limitation and the Importance of Nitrogen Requirements and Nitrogen Storage among Phytoplankton and Species of Macroalgae. Marine Ecology Progress Series, 142, 261-272. http://dx.doi.org/10.3354/meps142261

[56] Kamer, K. and Fong, P. (2001) Nutrient Enrichment Ameliorates the Negative Effects of Reduced Salinity on the Green Macroalga Enteromorpha intestinalis. Marine Ecology Progress Series, 218, 87-93. http://dx.doi.org/10.3354/meps218087

[57] Gordon, D.M., Birch, P.B. and McComb, A.J. (1981) Effects of Inorganic Phosphorus and Nitrogen on the Growth of an Estuarine Cladophora in Culture. Botanica Marina, 24, 93-106. http://dx.doi.org/10.1515/botm.1981.24.2.93

[58] Hanisak, M.D. (1979) Nitrogen Limitation of Codium fragile ssp. tomentosoides as Determined by Tissue Analysis. Marine Biology, 50, 333-337. http://dx.doi.org/10.1007/BF00387010

[59] Hanisak, M.D. (1993) Nitrogen Release from Decomposing Seaweeds: Species and Temperature Effects. Journal of Applied Phycology, 5, 175-181. http://dx.doi.org/10.1007/BF00004014

[60] Menéndez, M., Martinez, M. and Comín, F.A. (2001) A Comparative Study of the Effect of pH and Inorganic Carbon Resources on the Photosynthesis of Three Floating Macroalgae Species of a Mediterranean Coastal Lagoon. Journal of Experimental Marine Biology and Ecology, 256, 123-136. http://dx.doi.org/10.1016/S0022-0981(00)00313-0

[61] Björnsäter, B.R. and Wheeler, P.A. (1990) Effect of Nitrogen and Phosphorus Supply on Growth and Tissue Composition of Ulva fenestrata and Enteromorpha intestinalis (Ulvales, Chlorophyta). Journal of Phycology, 26, 603-611. http://dx.doi.org/10.1111/j.0022-3646.1990.00603.x

[62] Gressler, V., Yokoya, N.S., Fujii, M.T., Colepicolo, P., Mancini Filho, J., Torres, R.P. and Pinto, E. (2010) Lipid, Fatty Acid, Protein, Amino Acid and Ash Contents in Four Brazilian Red Algae Species. Food Chemistry, 120, 585-590. http://dx.doi.org/10.1016/j.foodchem.2009.10.028

[63] Peters, K.J., Amsler, C.D., Amsler, M.O., McClintock, J.B., Dunbar, R.B. and Baker, J. (2005) A Comparative Analysis of the Nutritional and Elemental Composition of Macroalgae from the Western Antarctic Peninsula. Phycologia, 44, 453-463. http://dx.doi.org/10.2216/0031-8884(2005)44[453:ACAOTN]2.0.CO;2

[64] Dawcznski, C., Schubert, R. and Jahreis, G. (2007) Amino Acids, Fatty Acids, and Dietary Fibre in Edible Seaweed Products. Food Chemistry, 103, 891-899. http://dx.doi.org/10.1016/j.foodchem.2006.09.041

[65] Polat, S. and Ozogul, Y. (2008) Biochemical Composition of Some Red and Brown Macro Algae from the Northeastern 
Mediterranean Sea. International Journal of Food Sciences and Nutrition, 59, 566-572. http://dx.doi.org/10.1080/09637480701446524

[66] Prabhasankar, P., Ganesan, P., Bhaskar, N., Hirose, A., Stephen, N., Gowda, L.R., Hosokawa, M. and Miyashita, K. (2009) Edible Japanese Seaweed, Wakame (Undaria pinnatifida) as an Ingredient in Pasta: Chemical, Functional and Structural Evaluation. Food Chemistry, 115, 501-508. http://dx.doi.org/10.1016/j.foodchem.2008.12.047

[67] Matanjun, P., Mohamed, S., Mustapha, N.M. and Muhammad, K. (2009) Nutrient Content of Tropical Edible Seaweeds, Eucheuma cottonii, Caulerpa lentillifera and Sargassum polycystum. Journal of Applied Phycology, 21, 75-80. http://dx.doi.org/10.1007/s10811-008-9326-4

[68] Fleurence, J., Morançais, M., Dumay, J., Decottignies, P., Turpin, V., Munier, M., Garcia-Bueno, N. and Jaouen, P. (2012) What Are the Prospects for Using Seaweed in Human Nutrition and for Marine Animals Raised through Aquaculture? Trends in Food Science \& Technology, 27, 57-61.http://dx.doi.org/10.1016/j.tifs.2012.03.004

[69] Munier, M., Dumay, J., Morançais, M., Jaouen, P. and Fleurence, J. (2013) Variation in the Biochemical Composition of the Edible Seaweed Grateloupia turuturu Yamada Harvested from Two Sampling Sites on the Brittany Coast (France): The Influence of Storage Method on the Extraction of the Seaweed Pigment R-Phycoerythrin. Journal of Chemistry, 2013, Article ID: 568548, 8 pages. http://dx.doi.org/10.1155/2013/568548

[70] Marinho-Soriano, E., Fonseca, P.C., Carneiro, M.A.A. and Moreira, W.S.C. (2006) Seasonal Variation in the Chemical Composition of Two Tropical Seaweeds. Bioresource Technology, 97, 2402-2406. http://dx.doi.org/10.1016/j.biortech.2005.10.014

[71] Yu, J. and Yang, Y.F. (2008) Physiological and Biochemical Response of Seaweed Gracilaria lemaneiformis to Concentration Changes of N and P. Journal of Experimental Marine Biology and Ecology, 367, 142-148. http://dx.doi.org/10.1016/j.jembe.2008.09.009

[72] Maurin, C. and Le Gal, Y. (1997) Glutamine Synthetase in the Marine Coccolithophorid Emiliania huxleyi (Prymnesiophyceae): Regulation of Activity in Relation to Light and Nitrogen Availability. Plant Science, 122, 61-69. http://dx.doi.org/10.1016/S0168-9452(96)04539-6

[73] Perfeto, P.N.M. (1998) Relation between Chemical Composition of Grateloupia doryphora (Montagne) Howe, Gymnogongrus griffithsiae (Turner) Martius, and Abiotic Parameters. Acta Botanica Brasilica, 12, 77-88.

[74] Renaud, S.M. and Luong-Van, J.T. (2006) Seasonal Variation in the Chemical Composition of Tropical Australian Marine Macroalgae. Journal of Applied Phycology, 18, 381-387. http://dx.doi.org/10.1007/s10811-006-9034-x

[75] Khairy, H.M. and El-Shafay, S.M. (2013) Seasonal Variations in the Biochemical Composition of Some Common Seaweed Species from the Coast of Abu Qir Bay, Alexandria, Egypt. Oceanologia, 55, 435-452. http://dx.doi.org/10.5697/oc.55-2.435

[76] Fleurence, J. (1999) Seaweed Proteins: Biochemical, Nutritional Aspects and Potential Uses. Trends in Food Science \& Technology, 10, 25-28. http://dx.doi.org/10.1016/S0924-2244(99)00015-1

[77] Rowan, K.S. (1989) Photosynthetic Pigments of Algae. Cambridge University Press, New York.

[78] Payri, C.E., Maritorena, S., Bizeau, C.E. and Rodière, M. (2001) Photoacclimation in the Tropical Coralline Alga Hydrolithon onkodes (Rhodophyta, Corallinaceae) from a French Polynesian Reef. Journal of Phycology, 37, $223-234$. http://dx.doi.org/10.1046/j.1529-8817.2001.037002223.x 